\title{
Inhibition of Carcinogen-Activating Cytochrome P450 Enzymes by Xenobiotic Chemicals in Relation to Antimutagenicity and Anticarcinogenicity
}

\author{
Tsutomu Shimada \\ Laboratory of Cellular and Molecular Biology, Graduate School of Life and Environmental Sciences, \\ Veterinary Sciences, Osaka Prefecture University, Osaka, Japan
}

(Received February 9, 2017; Accepted February 16, 2017)

\begin{abstract}
A variety of xenobiotic chemicals, such as polycyclic aromatic hydrocarbons (PAHs), aryl- and heterocyclic amines and tobacco related nitrosamines, are ubiquitous environmental carcinogens and are required to be activated to chemically reactive metabolites by xenobiotic-metabolizing enzymes, including cytochrome P450 (P450 or CYP), in order to initiate cell transformation. Of various human P450 enzymes determined to date, CYP1A1, 1A2, 1B1, 2A13, 2A6, 2E1, and 3A4 are reported to play critical roles in the bioactivation of these carcinogenic chemicals. In vivo studies have shown that disruption of CypIbI and Cyp2a5 genes in mice resulted in suppression of tumor formation caused by 7,12-dimethylbenz $[a]$ anthracene and 4-(methylnitrosamino)-1-(3-pyridyl)-1-butanone, respectively. In addition, specific inhibitors for CYP1 and 2A enzymes are able to suppress tumor formation caused by several carcinogens in experimental animals in vivo, when these inhibitors are applied before or just after the administration of carcinogens. In this review, we describe recent progress, including our own studies done during past decade, on the nature of inhibitors of human CYP1 and CYP2A enzymes that have been shown to activate carcinogenic PAHs and tobacco-related nitrosamines, respectively, in humans. The inhibitors considered here include a variety of carcinogenic and/or non-carcinogenic PAHs and acethylenic PAHs, many flavonoid derivatives, derivatives of naphthalene, phenanthrene, biphenyl, and pyrene and chemopreventive organoselenium compounds, such as benzyl selenocyanate and benzyl selenocyanate; $o$-XSC, 1,2-, 1,3-, and 1,4-phenylenebis(methylene)selenocyanate.
\end{abstract}

Key words: Cytochrome P450, Metabolic activation, Chemical carcinogenesis, Enzyme inhibition, Polycyclic aromatic hydrocarbons, Tobacco-related nitrosamines

\section{INTRODUCTION}

Rendic and Guengerich have recently summarized the roles of human xenobiotic metabolizing enzymes in the activation of a variety of environmental carcinogens and mutagens to chemically reactive metabolites by searching more than 500 literatures reported until 2012 (1). Cytochrome P450 (P450 or CYP), sulfotransferase, aldo-keto reductase, $N$-acetyltransferase, cyclooxygenase, and flavoncontaining monooxygenase are important enzymes involved
Correspondence to: Tsutomu Shimada, Laboratory of Cellular and Molecular Biology, Graduate School of Life and Environmental Sciences, Veterinary Science, Osaka Prefecture University, 1-58 RinkuOrai-Kita, Izumisano, Osaka 598-8531, Japan

E-mail: t.shimada@vet.osakafu-u.ac.jp

*Portion of this work has been presented at "Progress in Studies on the Antimutagenicity and Anticarcinogenicity" in the 32th Annual Meeting of KSOT/KEMS (November 3-4, 2016, Seoul, Korea).

This is an Open-Access article distributed under the terms of the Creative Commons Attribution Non-Commercial License (http:// creativecommons.org/licenses/by-nc/3.0) which permits unrestricted non-commercial use, distribution, and reproduction in any medium, provided the original work is properly cited.
Abbreviations: P450 or CYP, cytochrome P450; EROD, 7-ethoxyresorufin O-deethylation; $\mathrm{PAH}$, polycyclic aromatic hydrocarbon; $\mathrm{B}[a] \mathrm{P}$, benzo[a]pyrene; $\mathrm{B}[e] \mathrm{P}$, benzo[e]pyrene; 3-MC, 3-methylcholanthrene; 7,12-DMBA, 7,12-dimethybenzo[a]anthracene; $\mathrm{DB}[a, l] \mathrm{P}$, dibenzo[ $[a$, , $]$ pyrene (or dibenzo[def,p]chrysene); ANF, $\alpha$-naphthoflavone, NNK, 4-(methylnitrosamino)-1-(3-pyridyl)-1-butanone; Trp-P1, 3-amino-1,4-dimethyl-5H-pyrido[4,3-b]indole; Trp-P-2, 3-amino-1methyl-5H-pyrido[4,3-b]indole; 1PP, 1-(1-propynyl)pyrene; 1EP, 1ethynylpyrene; 4EP, 4-ethynylpyrene; 4Pbi, 4-propynyl biphenyl; BSC, benzyl selenocyanate; $o^{-}, m-$, and $p$-XSC, 1,2-phenylenebis(methylene)selenocyanate, 1,3-phenylenebis(methylene)selenocyanate, 1,4-phenylenebis(methylene)selenocyanate, respectively. 
in the metabolic activation of many carcinogens and their contributions to the activation of procarcinogens and promutagens have been estimated to be about $66 \%, 13 \%$, $8 \%, 7 \%, 2 \%$, and $1 \%$, respectively (1). P450 enzymes have been shown to play major roles in activating these carcinogens, based on the analysis of formation of chemically reactive metabolites, DNA adduct and damage, chromosomal abbreviation, and bacterial mutagenicity and genotoxicity assays such as Ames and umu test systems (2-8). Our previous studies using umu genotoxicity assay with human P450 enzymes in conjunction with the results obtained from Ames mutagenicity assay and other detection systems reported so far (6,7-19) have suggested that human CYP1A1, 1A2, 1B1, 2A6, 2A13, 2E1, and 3A4 are major enzymes involved in the activation of various environmental carcinogens including PAHs and tobacco-related nitrosamines (Table 1). In this review, we first describe in vivo studies on the roles of CYP1 and 2A enzymes in the formation of tumors caused by various chemical carcinogens; these are reported using gene-knockout mice and specific P450 inhibitors. Then, we summarize recent progress, mainly our in vitro studies done during the past decade, on the nature of chemical inhibitors of human P450 enzymes that participate in carcinogen activation (20-31).

In vivo studies of suppression of tumor formation caused by procarcinogens in gene knockout mice. Buters et al. (32) have first reported that disruption of Cyp1b1 gene in mice causes suppression of formation of malignant lymphomas and other tumors induced by 7,12DMBA as well as decreases in metabolizing 7,12-DMBA to a proximate carcinogenic 3,4-diol metabolite in primary embryoni stem cells (isolated from Cyp $1 b 1$ null mice) that had been treated with 2,3,7,8-tetrachlorodibenzo- $p$-dioxin (Table 2). These cell lines express Cyp1a1 protein at significant levels, but not Cyp1b1 protein, indicating that Cyp1b1 has a major role in activating 7,12-DMBA in vivo (32). The Cyplb1-null mice have also been reported to be reduced in

Table 1. Major human P450 enzymes involved in the bioactivation of chemical carcinogens

\begin{tabular}{|c|c|c|}
\hline P450 & Group of carcinogen & Carcinogens activated by $\mathrm{P} 450 \mathrm{~s}$ \\
\hline \multirow[t]{5}{*}{$\begin{array}{l}\text { CYP1A1 } \\
\text { CYP1A2 } \\
\text { CYP1B1 }\end{array}$} & PAH & $\begin{array}{l}\text { Benzo }[a] \text { pyrene }(\mathrm{B}[a] \mathrm{P}), 7,12 \text {-dimethylbenz }[\mathrm{a}] \text { anthracene }(7,12-\mathrm{DMBA}) \text {, benz }[a] \text { anthracene }(\mathrm{B}[a] \mathrm{A}) \text {, } \\
\text { benzo }[c] \text { phenenthrene, } 5 \text {-methylchrysene, dibenzo }[a, l] \text { pyrene }(\mathrm{DB}[a, l] \mathrm{P}, 3 \text {-methylcholanthrene }(3- \\
\mathrm{MC}) \text {, fluoranthene, and other PAHs, and their dihydrodiol derivatives }\end{array}$ \\
\hline & Arylamine & 2-Acetylaminofluorene, 2-aminofluorene, 2-aminoanthracene, 6-aminochrysene \\
\hline & Heterocyclic amine & $\begin{array}{l}\text { 2-Amino-3-methylimidazo[4,5-f }] \text { quinoline (IQ), 2-amino-3,5-dimethylimidazo[4,5-f }] \text { quinoline (MeIQ), } \\
\text { 2-amino-6-methyldipyrido[1,2- } a \text { : 3',2'- } d \text { imidazole (Glu-P-1), 3-amino-1,4-dimethyl-5H-pyrido[4,3- } \\
\text { b]indole (Trp-P-1), 2-amino-1-methyl-6-phenylimidazo[4,5-b]pyridine (PhIP), and others }\end{array}$ \\
\hline & Nitroarene & 1-Nitropyrene, 2-nitropyrene, 6-nitrochrysene \\
\hline & Estrogen & $17 \beta$-estradiol, estrone \\
\hline \multirow{3}{*}{$\begin{array}{l}\text { CYP2A6 } \\
\text { CYP2A13 }\end{array}$} & Nitrosamine & 4-(Methylnitrosamino)-1-(3-pyridyl)-1-butanone (NNK), $N$-nitrosonornicotine (NNN) \\
\hline & Mycotoxin & Aflatoxin $\mathrm{B}_{1}\left(\mathrm{AFB}_{1}\right)$ \\
\hline & Arylamine & 2-Aminofluorene, 2-aminoanthracene \\
\hline \multirow[t]{2}{*}{ CYP2E1 } & Nitrosamine & Dimethylnitrosamine, diethylnitrosamine, NNK, NNN \\
\hline & Arylhydrocarbon & Styrene \\
\hline CYP3A4 & Mycotoxin & Aflatoxin $\mathrm{B}_{1}$, aflatoxin $\mathrm{G}_{1}$, sterigmatocystin, dihydrodiol derivatives of PAHs \\
\hline
\end{tabular}

Table 2. Suppression of tumor formation caused by chemical carcinogens in gene knockout mice in vivo

\begin{tabular}{|c|c|c|c|}
\hline Disruption of gene & Carcinogen administered & Suppression of tumor formation in organs & Reference \\
\hline \multirow[t]{5}{*}{ Cyp $1 b 1$} & 7,12-DMBA & Lymphoid tissue & Buters et al. (32) \\
\hline & $\mathrm{DB}[a, l] \mathrm{P}$ & Ovary, skin, lymphoid tissue & Buters et al. (34) \\
\hline & 7,12-DMBA & Ovary & Buters et al. (33) \\
\hline & 7,12-DMBA & Spleen (immunotoxicity) & Gao et al. (39) \\
\hline & dibenzo[def,p]chrysene & Skin & Siddens et al. (36) \\
\hline Cyp2a5 & NNK & Lung & Megaraj et al. (47) \\
\hline Cyp2abfgs & NNK & Lung & Li et al. $(50)$ \\
\hline Cyp2e1 & Dimethylnitrosamine & Liver & Kang et al. (52) \\
\hline Epoxide hydrolase & 7,12-DMBA & Skin & Miyata et al. (40) \\
\hline Arylhydrocarbon receptor & $\mathrm{B}[a] \mathrm{P}$ & Skin & Shimizu et al. (41) \\
\hline
\end{tabular}


formation of ovarian cancers at a low dose of 7,12-DMBA (33), ovarian and skin tumors caused by $\mathrm{DB}[a, l] \mathrm{P}(34,35)$, and skin tumors by dibenzo[def, $p]$ chrysene $(\mathrm{DB}[a, l] \mathrm{P})(36)$. Disruption of Cyplb1-null mice has been shown to be reduced in pre-B cell apoptosis (37), bone marrow cytotoxicity (38), and spleen cell immunotoxicity (39) by treatment with 7,12-DMBA. Epoxide hydrolase and arylhydrocarbon hydroxylase have also been shown to play important roles in the formation of skin tumor caused by 7,12-DMBA and $\mathrm{B}[a] \mathrm{P}$, respectively, in gene knockout mice $(40,41)$.

Thus, roles of CYP1B1 protein in the activation of various carcinogenic PAHs have been suggested in gene knockout mice in vivo. Of note, Luch et al. (42) have found that CYP1B1 plays a more important role than CYP1A1 in activating $\mathrm{DB}[a, l] \mathrm{P}$ to highly reactive $\mathrm{DB}[a, l] \mathrm{P}-11,12$-diol13,14-epoxides and our previous in vitro studies have shown that human CYP1B1 is more active in forming $\mathrm{B}[a] \mathrm{P}-7,8-$ diol from $\mathrm{B}[a] \mathrm{P}$ than CYP1A1 and 1A2 (43). Uno et al. have reported that CYP1A1 may be involved in detoxification and protection against oral $\mathrm{B}[a] \mathrm{P}$ in mice, since CYP1A1 null mice died within 30 days after oral $\mathrm{B}[a] \mathrm{P}(125 \mathrm{mg} / \mathrm{kg})$, while wild-type mice did not show any signs of toxicity during the course of experiments (44). They also studied effects of oral $\mathrm{B}[a] \mathrm{P}$ in Cypla1-, la2-, and $1 b 1$-null mice and their double knockout mice and found that a balance of expression of Cypla1 and $1 \mathrm{~b} 1$ proteins in several organs is important to understand the basis of toxicity and carcinogenicity caused by oral administration of $\mathrm{B}[a] \mathrm{P}(45,46)$.

Megaraj et al. have shown that Cyp2A5-null mice are reduced in the formation of lung tumor caused by $\mathrm{NNK}$ and that CYP2A13 is suggested to play roles in bioactivating NNK to initiate lung tumor in a humanized mouse model (47). CYP2A13 genetic polymorphisms may cause individual differences in susceptibilities towards tobacco-related cancers in humans (47-49). In mice, other Cyp2-family enzymes as well as Cyp2a4 and 2a5 may be involved in NNK-induced tumor on analysis using Cyp2abfgs-null mice (49-51). Cyp2e1 has been reported to play key roles in the formation of liver tumors by dimethynitrosamine in the studies of gene knockout mice (52).

\footnotetext{
In vivo effects of P450 inhibitors on suppression of tumor formation caused by carcinogens in experimental animals. It has been reported that several PAH compounds suppress, prolong, or delay tumor formation caused by potent carcinogens such as 7,12-DMBA, B[a]P, dibenz $[a, h]$ anthracene, and $3-\mathrm{MC}$ in laboratory animals (Table 3) (53-58). Weak or non-carcinogen PAHs, such as $\mathrm{B}[e] \mathrm{P}$, have also been reported to reduce tumor fomation caused by environmental carcinogens (59-64), and as described below, $\mathrm{B}[e] \mathrm{P}$ has been determined to be a potent inhibitor for CYP1 family enzymes (20). CYP1 inhibitors such as ANF, 9-hydroxyellipticine, and 1-ethynylpyrene have also been reported to have anticarcinogenic activities
}

in mice treated with 7,12-DMBA and $\mathrm{B}[a] \mathrm{P}(56,65,66)$. Furanocoumarin derivatives (such as imperatorin and bergamottin) and flavonoids (such as naringenin, apigenin, quercetin, and hesperidin), which have been reported to inhibit human CYP1, 2A, and/or 3A enzymes in vitro $(23,24)$, have chemopreventive activities in experimental animals (67-73). 8-Methoxypsoralen and isothiocyanate derivatives, such as benzyl- and phenethyl isothiocyanates, which are the potent inhibitors of CYP2A6 and 2A13 $(74,75)$, have chemopreventive activities in mice when these chemicals are administered before or just after the administration of NNK and azoxymethane (Table 3) (74-80).

Synthetic organoselenium compounds such as BSC, and $o$-, $m$ - and $p$-XSC, which are recently reported by us to inhibit human CYP1 and 2A enzymes $(25,81)$, have chemopreventive activities in mice administered 7,12-DMBA, $\mathrm{B}[a] \mathrm{P}$, and NNK (Table 3) (82-89). El-Bayoumy et al. (87) reported that $p$-XSC is active in preventing tumor formation caused by NNK when it is injected before the administration of NNK, indicating that the mechanism of action of $p$-XSC is due to inhibition of P450s that activate NNK to active metabolites (47-51).

In vitro inhibition of carcinogen-activating P450 enzymes. Extensive studies have shown that there is a variety of xenobiotic and endogenous chemicals that inhibit individual forms of human P450s (6,20-26,90-92). Historically, many researchers have studied and searched specifc xenobiotic and endogenous inhibitors for P450 enzymes in order to examine roles of $\mathrm{P} 450 \mathrm{~s}$ in substrate oxidation reactions, to evaluate new drug development and drug-drug interaction in clinical trials, and to understand the basis of chemical toxicity and carcinogenesis (93-97). Following xenobiotic chemicals have been reported to be relatively specific inhibitors for individual human P450 enzymes; furafyllin, fluvoxamine, and a-naphthoflavone for CYP1 enzymes, methoxsalen, tranylcypromine, and tryptamine for CYP2A enzymes, ticlopine and thiotepa (triethylenethiophosphoramide) for CYP2B6, sulphaphenazole, fluconazole, and omeprazole for CYP2C enzymes, quinidine, terbinafine, and fluoxetine for CYP2D6, disulfiram, pyridine, and diethyldithiocarbamate for CYP2E1, and ketoconazole, itraconazole, and retionavir for CYP3A enzymes (6-8,20, 91,92,94).

Since CYP1A1, 1A2, 1B1, 2A6, and 2A13 have been recognized to be key enzymes in understanding the basis of chemical carcinogenesis caused by a variety of carcinogenic PAHs and tobacco-related nitrosamines, we summarize, mainly our recent studies during the past decade, on the nature of numerous xenobiotic chemicals that inhibit these human P450 enzymes (20-31). Followings are described here that a) inhibition of CYP1 enzymes by a variety of PAHs and acetylenic PAH inhibitors, b) different mechanisms of inhibition of CYP1 enzymes by PAHs and acetylenic PAH 
Table 3. Suppression by P450 inhibitors of tumor formation caused by chemical carcinogens in vivo by in laboratory animals (1)

\begin{tabular}{|c|c|c|c|c|}
\hline Inhibitor & $\begin{array}{l}\text { Suggested P450 } \\
\text { inhibition }\end{array}$ & Carcinogen administered & $\begin{array}{l}\text { Suppression of } \\
\text { tumor formation }\end{array}$ & Reference \\
\hline \multirow{3}{*}{$a$-Naphthoflavone } & CYP1 & 7,12-DMBA, B[a]P & Skin & Gelboin and Kinoshita (53) \\
\hline & CYP1 & 7,12-DMBA, B[a]P & Skin & Kinoshita and Gelboin (54) \\
\hline & CYP1 & 7,12-DMBA & Skin & Slaga et al. (56) \\
\hline 9-Hydroxyellipticine & CYP1 & 7,12-DMBA & Skin & Lesca and Mansuy (65) \\
\hline \multirow{2}{*}{ Benzo[e]pyrene } & CYP1 & 7,12-DMBA & Skin & DiGiovanni et al. (60) \\
\hline & CYP1 & Dibenz $[a, h]$ anthracene & Skin & DiGiovanni et al. (60) \\
\hline \multirow{2}{*}{ 1,2,5,6-Dibenzofluorene } & & 3-MC & Skin & Riegel et al. (57) \\
\hline & & 7,12-DMBA & Skin & Hill et al. (58) \\
\hline 1-Ethynylpyrene & CYP1 & 7,12-DMBA, B[a]P & Skin & Alworth et al. (66) \\
\hline Imperatorin & CYP1, 2A, 3A & 7,12-DMBA, $\mathrm{B}[a] \mathrm{P}$ & Skin & Cai et al. (67) \\
\hline Bergamottin & CYP1, 2A 3A & 7,12-DMBA & Skin & Kleiner et al. (68) \\
\hline Isopimpinellin & CYP1, 2A 3A & 7,12-DMBA & Skin & Kleiner et al. (68) \\
\hline Naringenin & CYP1, 2A & 7,12-DMBA & Oral & Sulfikkarali et al. (70) \\
\hline Apigenin & CYP1, 2A & 7,12-DMBA & Oral & Silvan et al. (71) \\
\hline Quercetin & CYP1, 2A & $\mathrm{NNK}, \mathrm{B}[a] \mathrm{P}$ & Lung & Kassie et al. (72) \\
\hline Hesperidin & CYP2C, 3A & Azoxymethane & Colon & Tanaka et al. (73) \\
\hline \multirow{4}{*}{ 8-Methoxypsoralen } & CYP2A & NNK & Lung & Takeuchi et al. (75) \\
\hline & CYP2A & NNK & Lung & Miyazaki et al. (76) \\
\hline & CYP2A & NNK & Lung & Takeuchi et al. (77) \\
\hline & CYP2A & NNK & Lung & Takeuchi et al. (74) \\
\hline \multirow{3}{*}{$\begin{array}{l}\text { Benzyl isothiocyanate } \\
\text { Phenyl isothiocyanate }\end{array}$} & CYP1, 2A & $\mathrm{B}[a] \mathrm{P}$ & Lung, stomach & Wattenberg et al. (78) \\
\hline & CYP2A & NNK & Lung & Morse et al. (79) \\
\hline & CYP2A & NNK & Lung & Morse et al. (80) \\
\hline \multirow{2}{*}{$\mathrm{BSC}$} & CYP1, 2A 3A & Azoxymethane & Colon & Fiala et al. (82) \\
\hline & CYP1, 2A 3A & $\mathrm{B}[a] \mathrm{P}$ & Stomach & El-Bayoumy (89) \\
\hline$p$-XSC, BSC & CYP1, 2A 3A & 7,12-DMBA & Mammary & El-Bayaumy et al. (84) \\
\hline \multirow{2}{*}{$p$-XSC } & CYP1, 2A 3A & 7,12-DMBA & Lung & Prokopczyk et al. (85) \\
\hline & CYP1, 2A 3A & $\mathrm{B}[a] \mathrm{P}, \mathrm{NNK}$ & Lung & Prokopczyk et al. (86) \\
\hline
\end{tabular}

inhibitors, c) inhibition of P450 enzymes by flavonoid derivatives, d) interaction of xenobiotic chemicals with CYP2A13 and 2A6, and e) inhibition of CYP1 and 2A enzymes by chemopreventive organoselenium compounds.

In vitro inhibition of CYP1A1, 1A2, and $1 B 1$ by xenobiotic chemicals. In humans, CYP1A1 and 1A2 share $80 \%$ amino acid seqence identity and are $\sim 40 \%$ identical with CYP1B1 (98-101). cDNA clones and amino acid sequences of former two enzymes have been characterized in 19851986 (98-100), while a human CYP1B1 cDNA clone and amino acid sequence were reported in 1994 (101). The crystal structures of CYP1A2 (102), CYP1B1 (103), and CYP1A1 (104) all bound to ANF in the active site cavity of the enzymes have been reported and characterized.

A variety of chemical inhibitors for human CYP1A1 and $1 \mathrm{~A} 2$ enzymes had been reported by many investigators (90,91,105-109). Since human CYP1B1 protein was not expressed in yeast and Escherichia coli and charactered until 1994-1997 $(16,104,110,111)$, studies on the comparison of selectivities of xenobiotic inhibitors for CYP1A1, $1 \mathrm{~A} 2$, and 1B1 were examined in 1998 by us (112) and by other investigators (113-117). We first examined total of 24 polycyclic hydrocarbons, many containing acetylenic side chains for their abilities to inhibit 7-ethoxyresorufin $O$ deethylation activities catalyzed by human CYP1A1, 1A2, and 1B1 (112). We found that 1-(1-propynyl)pyrene and 2-(1-propynyl)phenanthrene nearly completely inhibited CYP1A1 at concentrations where no CYP1B1 inhibition was observed and that 2-ethynylpyrene and ANF nearly completely inhibited CYP1B1 at concentrations where no CYP1A1 inhibition was noted. All four of the above compounds also inhibited CYP1A2. We conclude that (i) several polycyclic hydrocarbons and their oxidation products are inhibitors of human CYP1A1, 1A2, and 1B1; (ii) of these inhibitors only some are mechanism-based inactiva- 


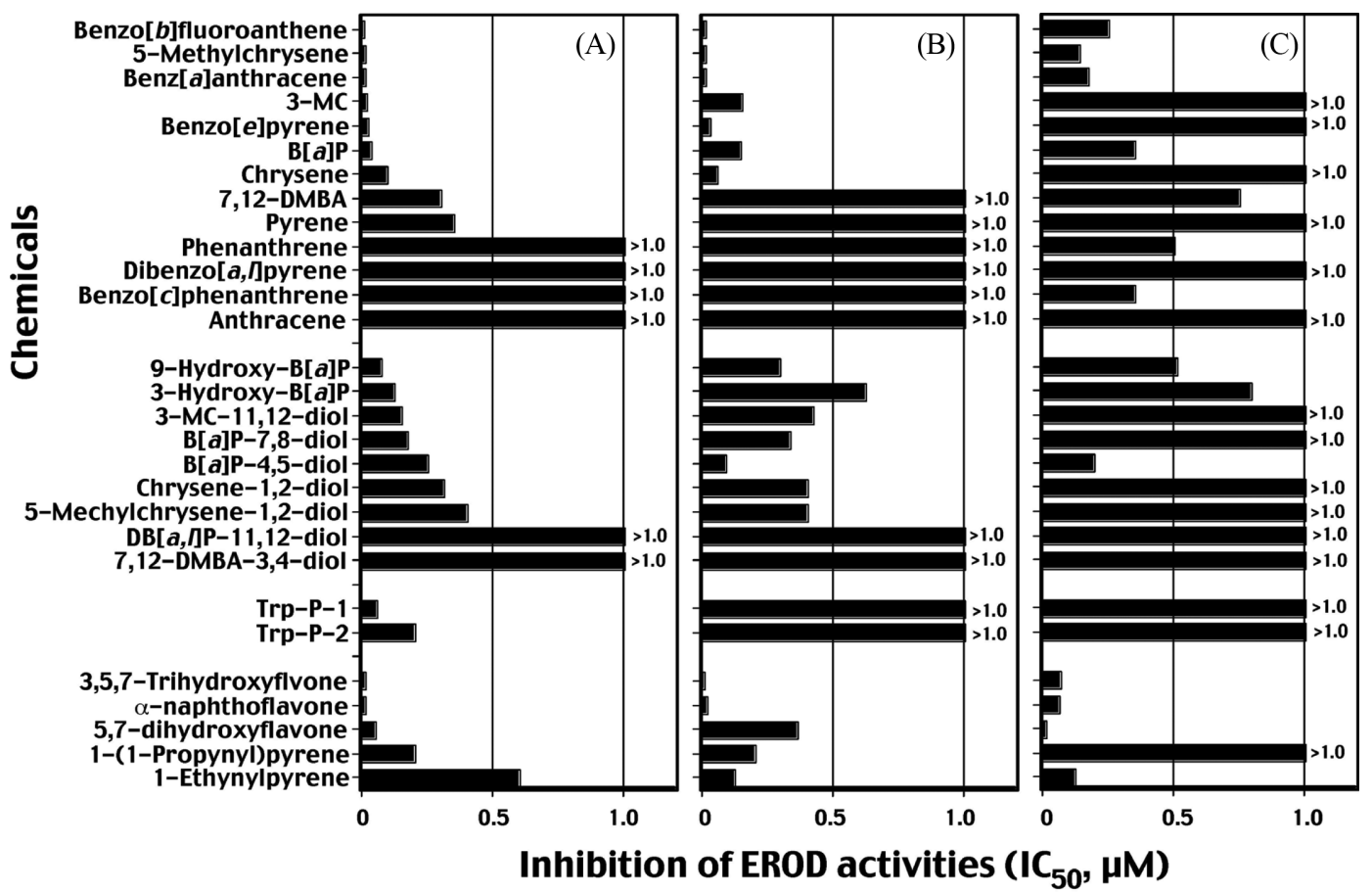

Fig. 1. Inhibition ( $I C_{50}$ values) of 7-ethoxyresorufin O-deethylation (EROD) activities of CYP1B1 (A), 1A2, (B), and $1 A 1$ (C) by PAHs, PAH metabolites, Trp-P-1 and Trp-P-2, and flavonoids and acetylenic PAHs. $I C_{50}$ values exceeded over $1.0 \mu \mathrm{M}$ are indicated in the figure. Data are taken from Shimada and Guengerich (20) with modification.

tors; and (iii) some of the inhibitors are potentially useful for distinguishing between human CYP1A1 and 1B1 (112).

In 2006, we studied if carcinogenic or non- or weak carcinogenic PAHs as well as acetylenic PAHs, inhibit CYP1catalytic activities (20), because some of these PAH compounds such as $\mathrm{B}[e] \mathrm{P}$ and 1,2,5,6-dibenzofluorene prevented tumor formation caused by carcinogenic PAH compounds as described above (57-64). We examined following chemicals as benzo[b]fluoranthene, 5-methylchrysene, $\mathrm{B}[a] \mathrm{A}, 3-\mathrm{MC}, \mathrm{B}[a] \mathrm{P}, \mathrm{B}[e] \mathrm{P}$, chrysene, 7,12-DMBA, pyrene, phenanthrene, $\mathrm{DB}[a, l] \mathrm{P}$, benzo $[c]$ phenanthrene, anthracene, pyrene, and phenanthrene and several $\mathrm{PAH}$ metabolites, Trp-P-1, Trp-P-2, and flavonoids (Fig. 1). In the figure, inhibition of EROD activities are shown as $\mathrm{IC}_{50}$ values within $1.0 \mu \mathrm{M}$ chemical concentration. Interestingly, $\mathrm{B}[a] \mathrm{A}$, benzo $[b]$ fluoranthene, and 5-methylchrysene inhibited CYP1B1- and 1A2-dependent EROD activities with $\mathrm{IC}_{50}$ values of below $0.01 \mu \mathrm{M}$. The $\mathrm{IC}_{50}$ values obtained with CYP1A1-dependent EROD activities were always higher than those with CYP1A2 and 1B1. Our results also showed that $\mathrm{B}[e] \mathrm{P}$ which have been reported to be weak or non-carcinogens (59-64), very strongly inhibited CYP1B1 and $1 \mathrm{~A} 2$ but not CYP1A1 at $1 \mu \mathrm{M}$ concentration. Conversely, potent carcinogens such as benzo[c]phenanthrene and $\mathrm{DB}[a, l] \mathrm{P}$ did not show significant inhibition of EROD activities by $\mathrm{P} 450 \mathrm{~s}$, except that the former PAH inhibited CYP1A1-dependent EROD activity with an $\mathrm{IC}_{50}$ of 0.33 $\mu \mathrm{M}$. Metabolites of PAHs (e.g., 3-OH and 9-OH B[a]P and dihydrodiol derivatives of PAHs) were rather weak inhibitors of P450-dependent EROD activities as compared with the parent PAHs. As suggested by us and other investigators, 3,5,7-trihydroxyflavone (galangin), 5,7-dihydroxyflavone (chrysin), and ANF were potent inhibitors for three CYP1 enzymes (20,105-108). Trp-P-1 and Trp-P-2 inhibited more strongly CYP1B1 than CYP1A1 and 1A2 (Fig. 1).

We also found that 5-methylchrysene, $\mathrm{B}[a] \mathrm{P}, \mathrm{B}[a] \mathrm{A}$, and $\mathrm{DB}[a, l] \mathrm{P}$ inhibited metabolic activation of 5-methylchrysene-1,2-diol, $( \pm) \mathrm{B}[a] \mathrm{P}-7,8$-diol, and $\mathrm{DB}[a, l] \mathrm{P}-11,12$-diol to genotoxic metabolites catalyzed by CYP1B1 and $1 \mathrm{~A} 1$ by measuring induction of $u m u$ gene expression in $S$. typhimurium NM2009 (20). The results suggest that these PAHs inhibit second step of metabolic activation of these dihydrodiols to DNA-damaging products as well as first step of metabolism (by measuring inhibition of EROD activitiy) (20). Thus, individual PAHs may affect their own and metabolism of other carcinogens catalyzed by CYP1A1, 1A2, and $1 \mathrm{~B} 1$, and these phenomena may cause alteration in their ability to transform cells when single or complex PAH mixtures are ingested by mammals, influencing risk assessment (113-117).

Different mechanisms of inhibition of P450 1A1-, 1A2-, and $1 B 1$ by PAHs and acetylenic PAH inhibitors. Since reports have shown that many acetylenic PAH inhibitors 

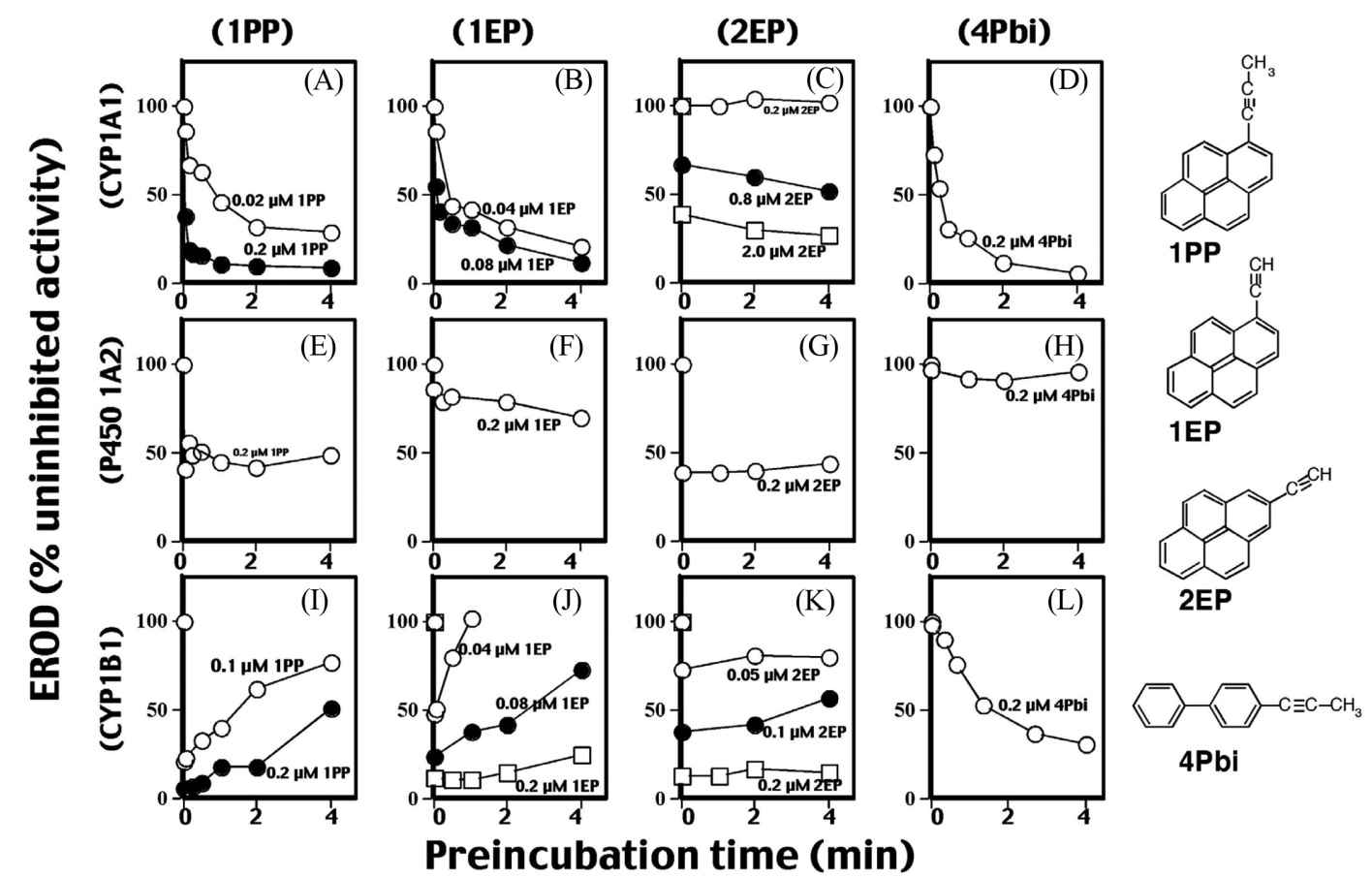

Fig. 2. Effects of preincubation time on inhibition of CYP1A1 (A-D), CYP1A2 (E-H), and CYP1B1 (I-L) dependent EROD activities by $1 P P$ $(A, E$, and $I), 1 E P(B, F$, and J), 2-EP (C, G, and K), and 4Pbi (D, H, and L). P450 (50 pmol) was pre-incubated with different concentrations of $1 \mathrm{PP}, 1 \mathrm{EP}, 2 \mathrm{EP}$, and $4 \mathrm{Pbi}$ in the presence of $1 \mathrm{mM}$ NADPH during indicated periods of time, and then the reactions were started by the addition of $5 \mu \mathrm{M}$ 7-ethoxyresorufin to determine EROD activities. The reactions were monitored at $25^{\circ} \mathrm{C}$. Data are taken from Shimada et al. (21) with modification.

inhibit P450-catalytic activities by mehanism-based manner $(20,66,97,118-120)$, we have studied mechanisms of inhibition of CYP1-dependent EROD activities by PAHs used in this study (Fig. 2) (20-23). Our initial experiments show that preincubation of 1PP, 1EP, and 4Pbi with CYP1A1 for $0-4$ min in the presence of NADPH caused inhibition of EROD activities in a time-dependent manner, indicating inhibition by a mechanism-based manner (Fig. 2A, 2B, 2D). However, 2EP inhibits P450 1A1 directly (preincubation does not affect the activities) (Fig. 2C) (21). CYP1B1dependent EROD activity was inhibited by 1PP and 1EP without metabolism, and such decreases in activities were reversed with increasing pre-incubation time, indicating that CYP1B1 is able to metabolize 1PP and 1EP to products that loose inhibitory activity (relief of inhibition via metabolism) (Fig. 2I, 2J, 3). 4Pbi inhibited CYP1B1 in a mechanism-based manner similar to CYP1A1, although such inactivation in CYP1B1 $\left(\mathrm{t}_{1 / 2}=3.4 \mathrm{~min}\right)$ was slower than that of the CYP1A1 ( $\left.\mathrm{t}_{1 / 2}=15 \mathrm{~s}\right)$ (Fig. 2L, 2D). 2EP inhibited CYP1B1 directly. Four chemicals inhibited CYP1A2 directly (Fig. 2E-2H). These results indicated that there are three different mechanisms of inhibition of CYP1-enzymatic activities; a) direct inhibition, b) mehanism-based imnhibition (competitve inhibition), and c) relief of inhibition via metabolism as seen in 1PP and 1EP with CYP1B1 (Fig. 3). The mehanism namely, relief of inhibition via metabolism, was also observed in $\mathrm{B}[a] \mathrm{A}, \mathrm{B}[a] \mathrm{P}, \mathrm{B}[e] \mathrm{P}, 5-$ methylchrysene, and 7,12-DMBA with CYP1B1, although chrysene and 3-MC inhibited CYP1B1 by competitive manner (21). Interestingly, these PAHs as $\mathrm{B}[a] \mathrm{A}$, benzo $[b]$ fluoranthene, benzo[j]fluoranthene, $\mathrm{B}[a] \mathrm{P}$, chrysene, 5-methylchrysene, $\mathrm{B}[e] \mathrm{P}$, dibenz $[a, j]$ acridine, and 7,12-DMBA inhibited CYP1A2 by mechanism-based manner and inhibited CYP1A1 by a competiotive manner (20). Thus, these PAHs may modify the biological activities of their own and other PAH compounds through inhibition of CYP1-catalytic activities by different mechanisms (20.21).

\section{Inhibition of P450 enzymes by flavonoid derivatives.}

A variety of plant flavonoids are found in the environment and these natural products are shown to have various biological properties, e.g. anti-oxidative and anti-mutagenic activities, thus preventing cancer, heart disease, bone loss, and a number of diseases (121-123). These biological activities are reported to vary with the number and substitution positions of hydroxyl and/or methoxy groups in the flavonoid molecules (124-126). Inhibition of P450 enzymes by diverse flavonoid erivatives has been extensively studied in several laboratories (127-137).

In 2009, we have reported that various chemicals including flavonoid, stilbene, pyrene, naphthalene, and biphenyl and their derivatives interact with CYP1B1 inducing reverse 


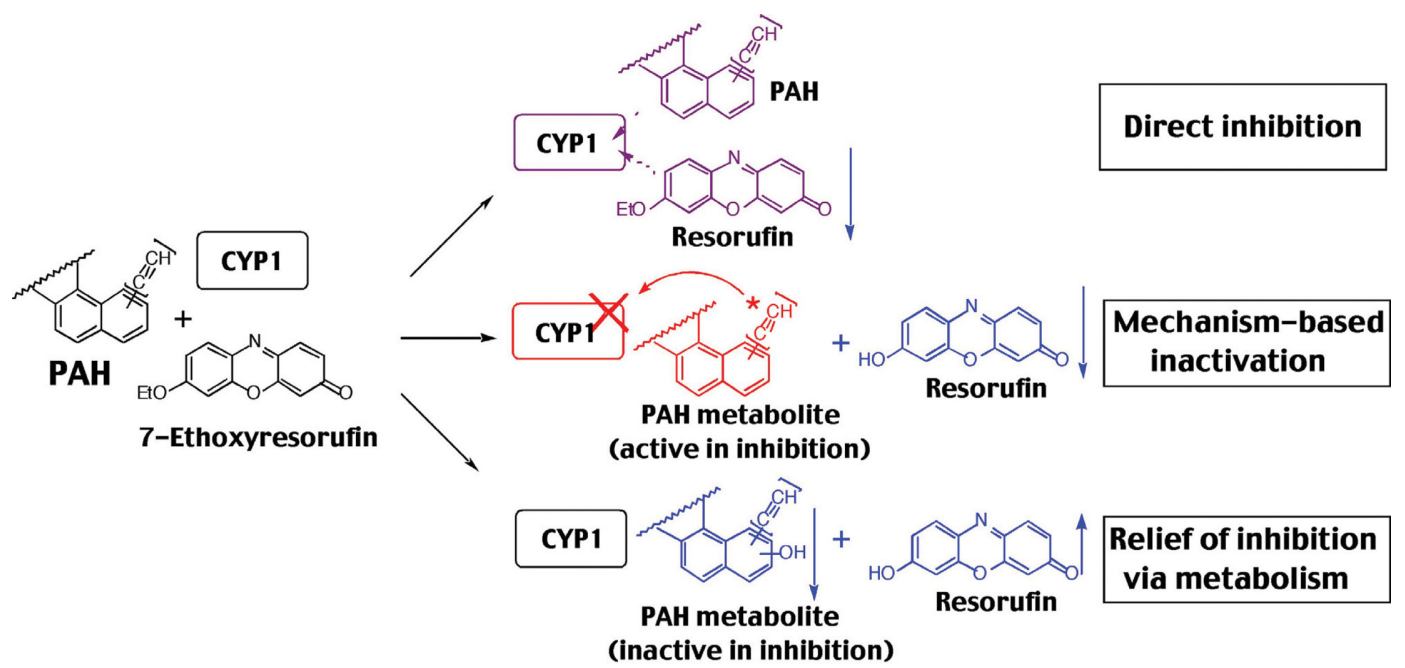

Fig. 3. Three different mechanisms of inhibition of CYP1 enzymes by PAHs and acetylenic PAHs. Data are from Shimada et al. (21).

type I binding spectra and that these spectral changes are correlated with abilities to inhibit CYP1B1-dependent EROD activities (23). We further examined the relationship between spectral interaction of CYP1B1, 1A1, 1A2, 2C9, and 3A4 with total of 33 flavonoid derivatives and their potencies ( $\mathrm{IC}_{50}$ values) to inhibit $\mathrm{P} 450$ catalytic activities by measuring EROD activities for CYP1B1, 1A1, and 1A2, flurbinoprofen 4'-hydroxylation activities for CYP2C9, and midazolam 4-hydroxylation activities for CYP3A4 (Fig. 4) (24). In the figure, results with selected 27 flavonoid derivatives are shown and the scale of $\mathrm{IC}_{50}$ values vary with $1 \sim$ $2.0 \mu \mathrm{M}$ for CYP1B1, 0 5.0 $\mu \mathrm{M}$ for CYP1A2 and 1A1, 0 $30 \mu \mathrm{M}$ for CYP2C9, and $0 \sim 100 \mu \mathrm{M}$ for CYP3A4 (Fig. 4). The potencies of spectral binding of CYP1B1 were found to correlate with the abilities to inhibit 7-ethoxyresorufin $O$ deethylation activity catalyzed by CYP1B1 $(r=0.92)$. The presence of a hydroxyl group in flavone, e.g. 3-, 5-, and 7monohydroxy- and 5,7-dihydroxyflavone (chrysin), decreased the $50 \%$ inhibition concentration $\left(\mathrm{IC}_{50}\right)$ of CYP1B1 from $0.6 \mu \mathrm{M}$ (with flavone) to $0.09,0.21,0.25$, and $0.27 \mu \mathrm{M}$, respectively, and 3,5,7-trihydroxyflavone (galangin) was the most potent, with an $\mathrm{IC}_{50}$ of $0.003 \mu \mathrm{M}$. The introduction of a 4'-methoxy- or 3',4'-dimethoxy group into 5,7dihydroxyflavone yielded other active inhibitors of CYP1B1 with $\mathrm{IC}_{50}$ values of 0.014 and $0.019 \mu \mathrm{M}$, respectively. The above hydroxyl- and/or methoxy- groups in flavone molecules also increased the inhibition activity with CYP1A1 but not always towards CYP1A2, where 3-, 5-, or 7hydroxyflavone, and 4'-methoxy-5,7-dihydroxyflavone were less inhibitory than flavone itself, although CYP1A1 and $1 \mathrm{~A} 2$ did not show spectral changes with these compounds. CYP2C9, which was also negative in inducing spectral changes with flavonoids, was more inhibited by 7-hydroxy-, 5,7-dihydroxy-, and 3,5,7-trihydroxyflavones than by flavone but was weakly inhibited by 3- and 5-hydroxyfla- vone. Flavone and several other flavonoids produced type I binding spectra with CYP3A4, but such binding was not always related to the inhibitiory activities towards CYP3A4 (24). The $\mathrm{IC}_{50}$ values with flavonoids to inhbit CYP2C9 and 3A4 were higher than those to inhibit CYP1B1, 1A2, and 1A1 (Fig. 4). These results indicate that there are different mechanisms of inhibition for CYP1A1, 1A2, 1B1, 2C9, and $3 \mathrm{~A} 4$ by various flavonoid derivatives and that the number and position of hydroxyl and/or methoxy groups highly influence the inhibitory actions of flavonoids towards these enzymes.

Our molecular docking analysis supported that there are different orientations of interaction of various flavonoids with active sites of P450 enzymes examined, thus causing differences in inhibition potencies observed in these P450s (24).

Interaction of xenobiotic chemicals with human CYP2A13 and 2A6. CYP2A6 and 2A13 are expressed mainly in the liver and respiratory tract, respectively, in humans $(4,138,139)$. CYP2A6 is active in catalyzing metabolism of several drugs, e.g. coumarin and phenacetin, and also metabolic activation of tobacco-related nitrosamines (including $\mathrm{NNK}$ and $\mathrm{NNN}$ ) to carcinogenic metabolites $(140,141)$. However, CYP2A13 is shown to be more active than CYP2A6 in activating NNK and NNN $(140,141)$ and these findings are of interest because the latter enzyme is mainly expressed in respiratory organs, the sites of exposure to numerous environmental chemicals including NNK, NNN, and PAHs $(4,138,139)$. As described above, several chemicals that inhibit CYP2A13 and 2A6 enzymes suppress tumor formation caused by NNK, 7,12-DMBA, B $[a] \mathrm{P}$, and azoxymethane (Table 3) (47-51), it is interesting to examine whether various xenobiotic chemicals interact with and inhibit CYP2A13 and 2A6-dependent catalytic activi- 


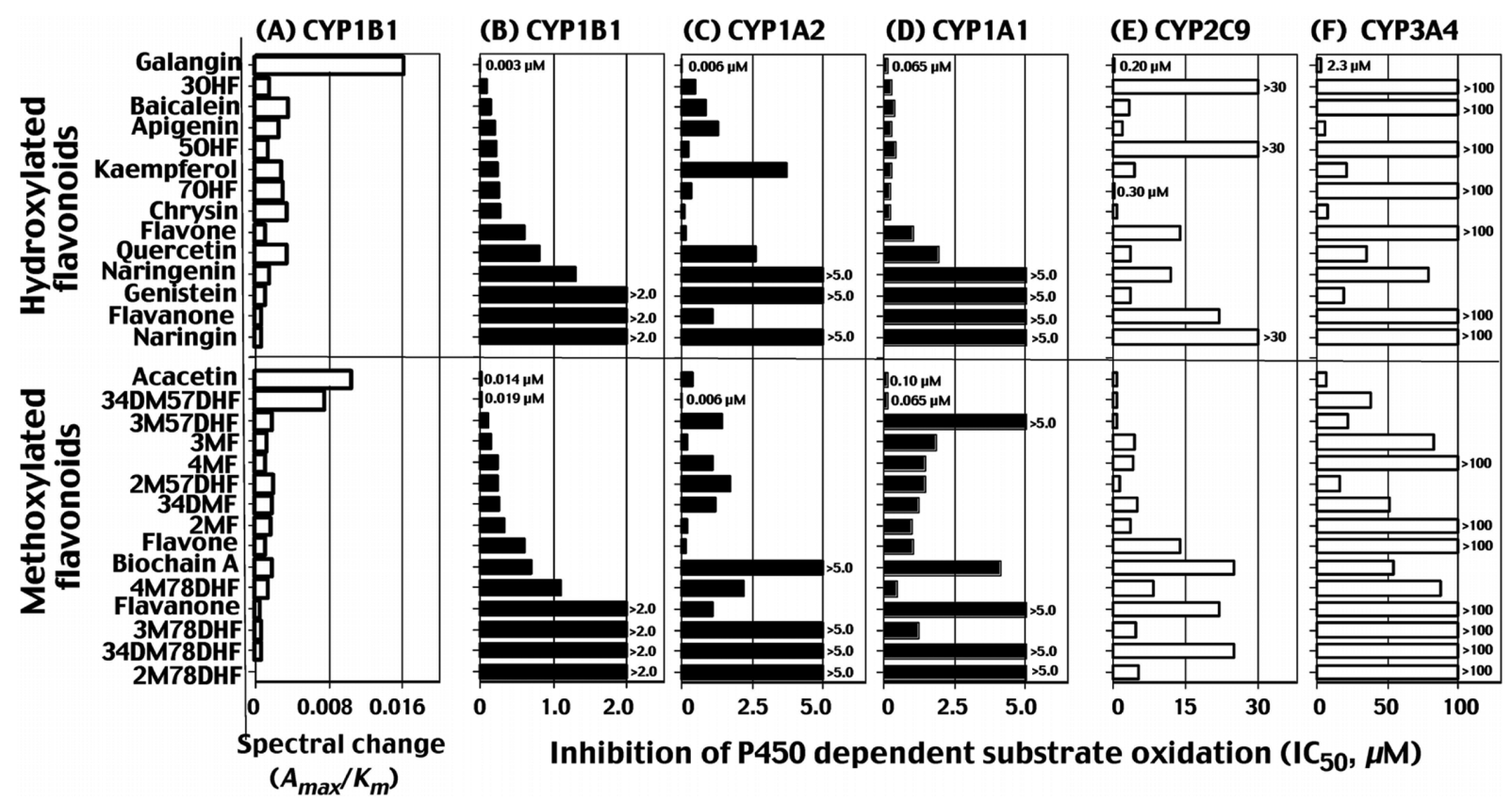

Fig. 4. Intensities of reverse type I binding spectra of CYP1B1 with 27 flavonoids (A) and inhibition by these flavonoids of EROD activities catalyzed by CYP1B1 (B), 1A1 (C), and 1A2 (D), flurbiprofen 4'-hydroxylation activities catalyzed by CYP2C9 (E), midazolam 4hydroxylation activities catalyzed by CYP3A4 (F). The spectral changes are shown as spectral binding efficiency $\left(\Delta A_{\max } / K_{m}\right.$ values). IC values are shown to be $0 \sim 1.0 \mu \mathrm{M}$ for CYP1B1, 1A2, and 1A1, and 0 30 $\mu \mathrm{M}$ for CYP2C9 and 3A4. Abbreviations used; 3HF, 3-hydroxyflavone; 5HF, 5-hydroxyflavone; 7HF, 7-hydroxyflavone; 57DHF, 5,7-dihydroxyflavone; 357THF, 3,5,7-trihydroxyflavone; 4'57THF, 4'5,7-trihydroxytrihydroxyflavone; 4'57THIF, 4',5,7-trihydroxyisoflavone; 4'57THFva, 4',5,7-trihydroxyflavanone; 4'57THFvaG, 4',5,7-trihydroxyflavanone glycoside; 567THF, 5,6,7-trihydroxyflavone; 34'57TetraHF, 3,4'5,7-tetrahydroxyflavone; 33'4'57PHF, 3,3'4',5,7-pentahydroxyflavone; 4'M57DHF, 4'-methoxy-5,7-dihydroxyflavone; 4'M57DHisoF, 4'-methoxy-5,7-dihydroxyisoflavone; 2'MF, 2'-methoxyflavone; 3'MF, 3'-methoxyflavone; 4'MF, 4'-methoxyflavone; 3'4'DMF, 3',4'-dimethoxyflavone; 2'M57DHF, 2'-methoxy-5,7-dihydroxyflavone; 3'M57DHF, 3'-methoxy-5,7-dihydroxyflavone; 3'4'M57DHF, 3'4'-dimethoxy-5,7-dihydroxyflavone; 2'M78DHF, 2'-methoxy-7,8-dihydroxyflavone; 3'M78DHF, 3'-methoxy-7,8dihydroxyflavone; 4'M78DHF, 4'-methoxy-7,8-dihydroxyflavone; and 3'4'M78DHF, 3'4'-dimethoxy-7,8-dihydroxyflavone. Data are taken from Shimada et al. (30) with modification.

ties and are metabolized by these P450 enzymes (26,27).

A total of 68 chemicals including acenaphthene, acenaphtylenes, derivatives of naphthalene, phenanthrene, fluoranthene, pyrene, biphenyl, and flavone have been examined for their abilities to interact with human CYP2A13 and 2A6 (Fig. 5) (26). Fifty-one of these 68 chemicals induced stronger type I binding spectra (iron low- to high-spin state shift) with CYP2A13 than those seen with CYP2A6, i.e. the spectral binding intensities $\left(\triangle A_{\max } / K_{\mathrm{s}}\right.$ ratio) determined with these chemicals were always higher for CYP2A13. In addition, benzo[c]phenanthrene, fluoranthene, 2,3-dihydroxy2,3-dihydrofluoranthene, pyrene, 1-hydroxypyrene, 1-nitropyrene, 1-acetylpyrene, 2-acetylpyrene, 2,5,2',5'-tetrachlorobiphenyl, 7-hydroxyflavone, 5,7-dihydroxyflavone (chrysin), and 3,5,7,-dihydroxyflavone (galangin) were found to induce a type I spectral change only with CYP2A13. Coumarin 7hydroxylation, catalyzed by CYP2A13, was strongly inhibited by acenaphthene, acenaphthylene, 2-ethynylnaphthalene, 2-naphththalene propargyl ether, 2-naphthalene ethyl propagyl ether. 3-ethynylphenanthrene, 1-acetylpyrene, flavone, flavanone, 7-hydroxyflavone, 2'-methoxyflavone, 5,7- dihydroxyflavone, and 2'-methoxy-5,7-dihydroxyflavone; these chemicals induced type I spectral changes with low $K_{\text {s }}$ values (Fig. 5). Among various chemicals tested, benzo $[c]$ phenanthrene, fluoranthene, pyrene, 1-hydroxypyrene, 1-nitropyrene, 1- and 2-acetylpyrene, 2,5,2',5'-tetrachlorobiphenyl, 7-hydroxyflavone, 5,7-dihydroxyflavone (chrysin), 3,5,7-trihydroxyflavone (galangin), and ANF did not induce spectral changes with CYP2A6 (26). These chemicals were also found to be non-inhibitory or weak inhibitors of CYP2A6-dependent coumarin 7-hydroxylation activity. Thus, different selectivities of several chemicals in inducing spectral changes with these CYP2A enzymes were found, although it should be noted that 2-ethynylnaphthalene, naphthalene, 1-(1-propynyl)pyrene, 1-ethynylpyrene, 2-ethynylnaphthalene, phenanthrene, acenaphthene, acenaphthylene, biphenyl, and resveratrol had relatively similar tendencies to induce spectra with CYP2A13 and 2A6 (26).

Twenty four chemicals including naphthalene, phenanthrene, biphenyl and their derivatives have been determined and compared to induce type I spectral changes 


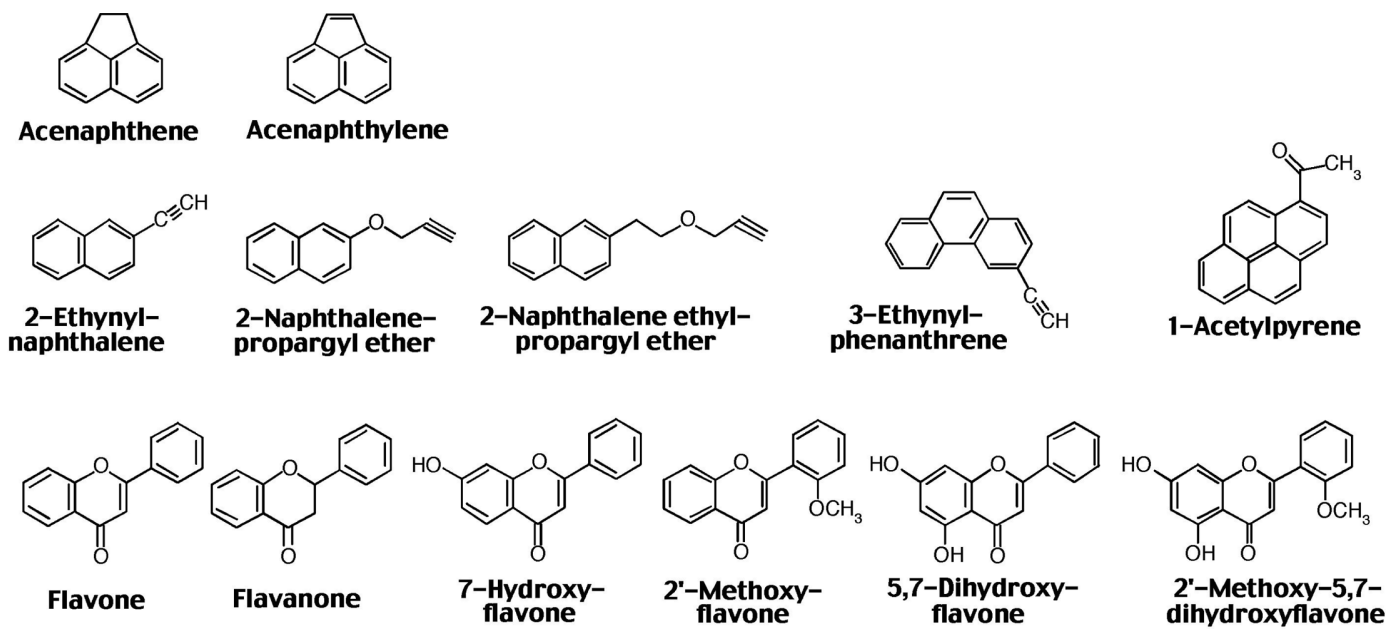

Fig. 5. Compounds that show strong inhibition of CYP2A13-dependent coumarin 7-hydroxylation activities. Data are taken from Shimada et al. (26) with modification.

(intensities, $A_{\max } / K_{s}$ ratio) with CYP2A13 (Fig. 6A) and 2A6 (Fig. 6B) and to inhibit coumarin 7-hydroxylation catalyzed by CYP2A13 (Fig. 6C) and 2A6 (Fig. 6D) (26,2830). All of these chemicals induce type I binding spectra with CYP2A13 having high affinities with 2-ethynylnaphthalene, 2-naphthalene propargyl ether, naphthalene, 1naphthalene ethylpropargyl ether, 2-naphthalene ethylpropargyl ether, 3-ethynylnaphthalene, 9-ethynylnaphthalene, 3(1-propynyl)phenanthrene, 2-ethynylnaphthalene, 2-(1-propynyl)phenanthrene, phenanthrene, 4-biphenyl propargyl ether, biphenyl, and 4-ethynylbiphenyl (Fig. 6A). These spectral intensities in CYP2A13 tended to relate to the potencies of these chemicals to inhibit coumarin 7-hydroxylation activities catalyzed by this enzyme (Fig. 6C). All of these 24 chemicals also interacted with CYP2A6, however, spectral intensities and inhibition of coumarin 7-hydroxylation activities found in CYP2A6 were lesser than those in CYP2A13, except that 4-propynylbiphenyl inhibited CYP2A6 $\left(\mathrm{IC}_{50}=70 \mu \mathrm{M}\right)$ more than CYP2A13 $\left(\mathrm{IC}_{50}>200 \mu \mathrm{M}\right)$; this compound was less active in inducing type I binding spec-
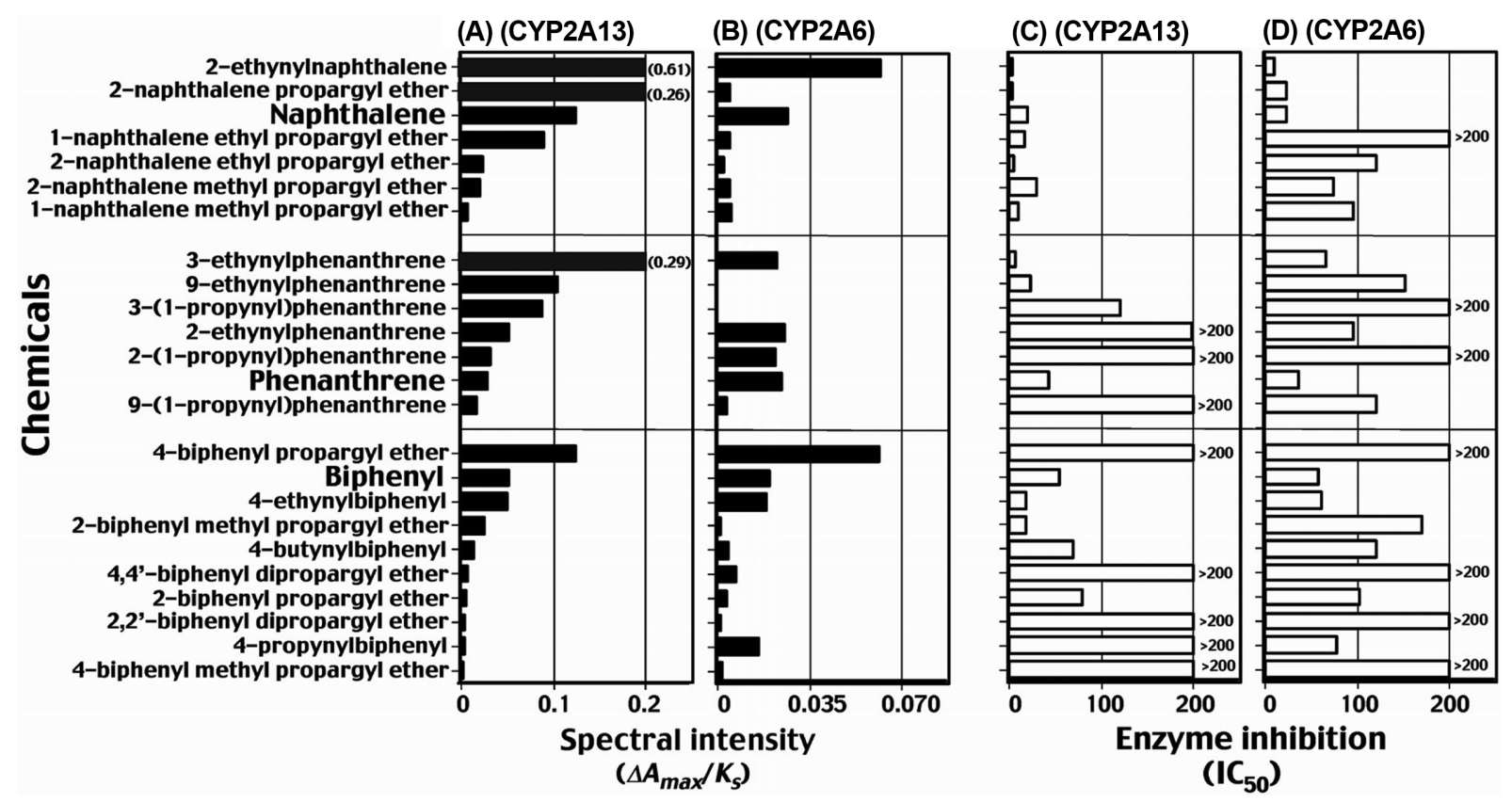

Fig. 6. Type I binding spectra of interaction of naphthalene, phenanthrene, biphenyl, and their derivatives with CYP2A13 (A) and $2 A 6$ (B) and inhibition of coumarin 7-hydroxylation activities of CYP2A13 (C) and 2A6 (D) by these chemicals. Data are taken from Shimada et al. $(26,28-30)$ with modification. 


\begin{tabular}{|lcccc|}
\hline & \multicolumn{4}{c|}{ Modeled CYP2A13 structure } \\
\cline { 2 - 5 } Ligand & 4EJH & 2P85 & 3T3S & 4EJG \\
& NNK & Indole & Pilocarpine & Nicotine \\
\hline \multicolumn{5}{c}{ (ligand-interaction energies) } \\
2EN & -7.6 & -33 & -24 & -32 \\
2EPh & -9.8 & -25 & -18 & -26 \\
4BPE & 4.2 & -4.9 & -28 & -19 \\
\hline
\end{tabular}

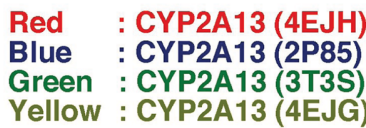

Yellow : CYP2A13 (4EJG)
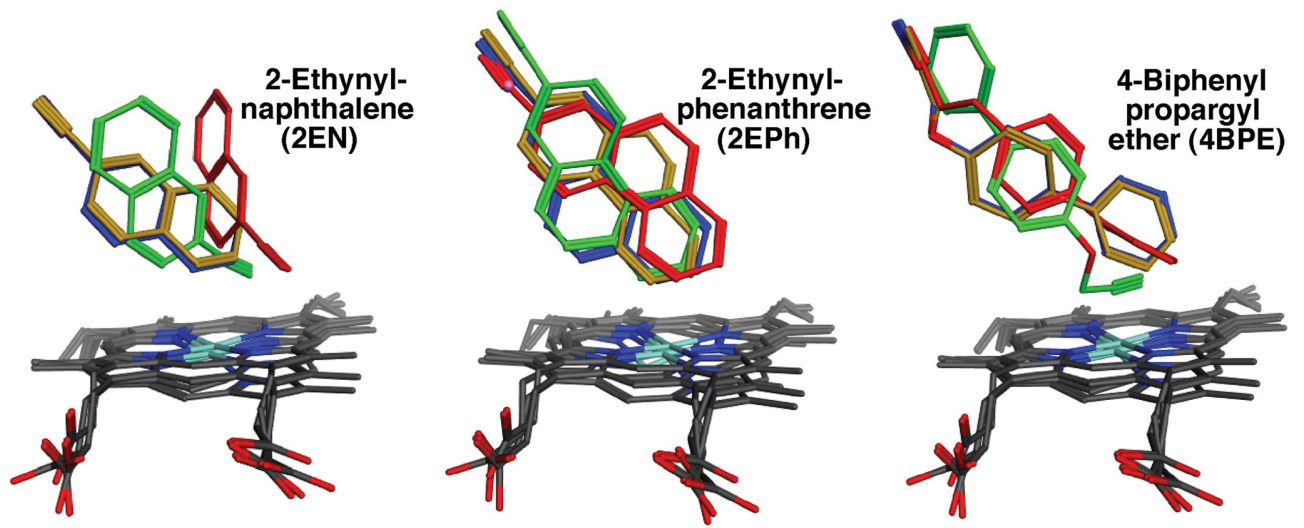

Fig. 7. Molecular docking analysis of ligand-interaction energies ( $U$ values) of 2-ethynylnaphthalene, 2-ethynylphenanthrene, and 4biphenyl propargyl ether obtained using reported crystal structures of CYP2A13 (4EJH), 2A13 (2P85), 2A13 (3T3S), and 2A13 (4EJG) bound to NNK, indole, pilocarpine, and nicotine, respectively. Data are from Murayama, N., Shimada, T. and Yamazaki, H. (unpublished results).

tra with CYP2A13 (Fig. 6C, 6D).

Since molecular docking analysis has been shown to be a useful tool for the studies of the interactions of various ligands with active sites of enzymes, such as P450s, we examined and compared the ligand-interaction energies ( $U$ values) with these 24 chemicals using reported crystal structures of CYP2A13 (4EJH), 2A13 (2P85), 2A13 (3T3S), and 2A13 (4EJG) (142-144) bound to NNK, indole, pilocarpine, and nicotine, respectively, and CYP2A6 (1Z10), 2A6 (3T3R), and $2 \mathrm{~A} 6 \mathrm{4EJJ})(145,146)$ bound to coumarin, pilocarpine, and nicotine, respectively (30). We first determined the $U$ values of interaction of 2-ethynylnaphthalene, 2-ethynylphenanthrene, and 4-biphenylpropagyl ether with CYP2A13 (4EJH), CYP2A13 (2P85), CYP2A13 (3T3S), and CYP2A13 (4EJG) (Fig. 7) and obtained optimal $U$ values on analysis with MMFF94x force field (30). The $U$ values are somewhat different when different crystal structures of CYP2A13 were used (Fig. 7).

In order to examine structure-function relationships of the interactions of above 24 chemicals with active sites of CYP2A13 and CYP2A6, we compared the $U$ values obtained with CYP2A13 4EJG (nicotine type) and CYP2A13 4EJH (NNK type) (Fig. 8A) and CYP2A6 4EJJ (nicotine type) and CYP2A6 3T3R (pilocarpine type) (Fig. 8B) (30). There were good correlations between $U$ values of CYP2A13 4EJG (nicotine-type) and 4EJH (NNK-type) $(r=0.79, p<$ 0.01 ) and of CYP2A6 4Ejj (nicotine-type) and 2A6 3T3R (pilocarpine-type) $(r=0.93, p<0.01)$ with these 24 chemi- cals and also with NNK, indole, pilocarpine, and nicotine as standards for CYP2A substrates (Fig. 8) (140-144). It was also found that the parent compounds, naphthalene, phenanthrene, and biphenyl had $U$ values comparable to those of NNK, indole, pilocarpine, nicotine, and coumarin (Fig. 8). The results support the usefulness of molecular docking analysis in understanding the basis of molecular interaction of xenobiotic chemicals with the active sites of $\mathrm{P} 450$ proteins and possibly other enzymes.

Very recently, we carried out in vitro studies if these chemicals that interact with and inhibit CYP2A13 and 2A6 are oxidized by these enzymes $(26,28-31)$. The results obtained showed that CYP2A13 is the major enzyme in 1-hydroxylation of pyrene, 8-hydroxylation of 1-hydroxypyrene (to form 1,8-dihydroxypyrene), hydroxylation of 1-nitropyrene and 1-actylpyrene (26). CYP2A13 also oxidized naphthalene, phenanthrene, and biphenyl to 1-naphthol, 9-hydroxyphenanthrene, and 2- and/or 4-hydroxybiphenyl, respectively (30). Our results also showed that acetylenic PAH compounds such as 2-ethynylnaphthalene, 1-naphthalene ethyl propargyl ether, 2-naphthalene propargyl ether, 2-ethynylphenanthrene, 3-ethynylphenanthrene, 2-(1-propynyl)phenanthrene, 3-(1-propynyl)phenanthrene, and 4-biphenyl propargyl ether which interact highly with CYP2A13 were found to be metabolized by this enzyme (30). In contrast, 2,5,2',5'tetrachlorobiphenyl was found to be oxidized by CYP2A6 to form 4-hydroxylated metabolite at a much higher rate than by CYP2A13 (31). 

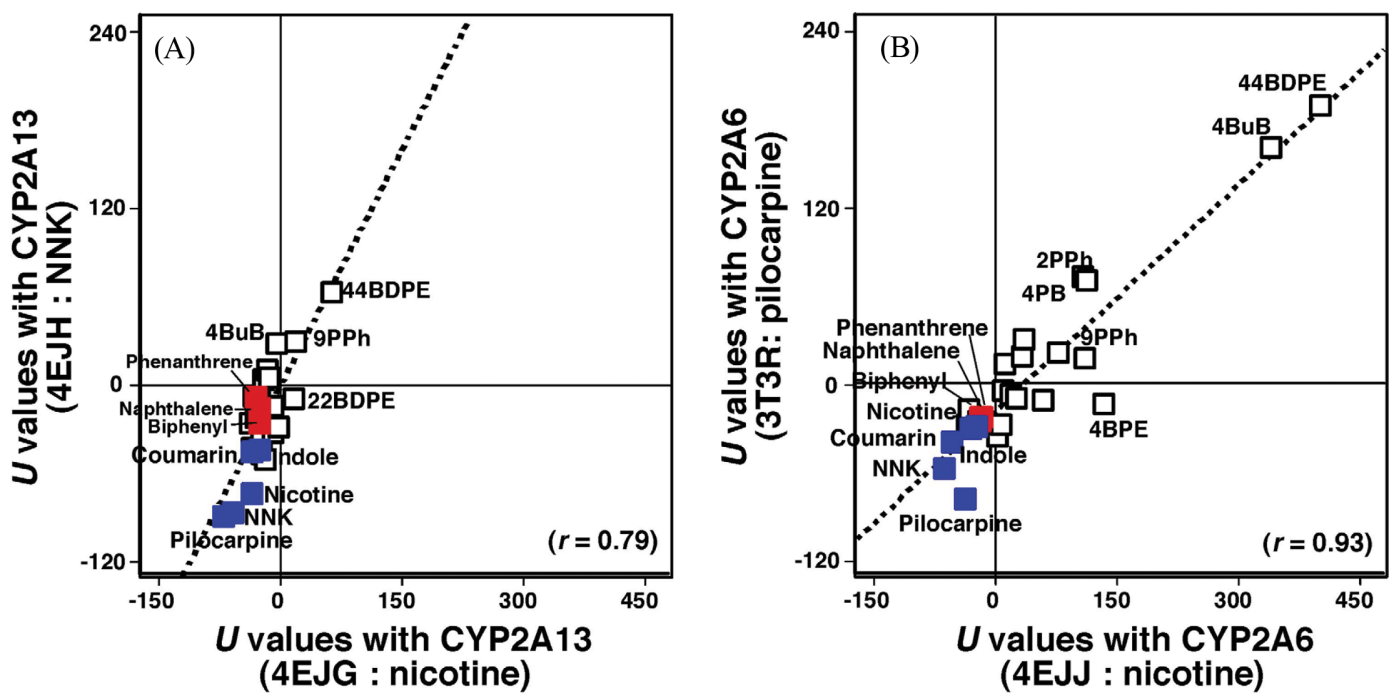

Fig. 8. Correlations of ligand-interaction energies ( $U$ values) of interaction of 24 chemicals (and also NNK, indole, pilocarpine, nicotine, and coumarin) with crystal structures of CYP2A13 4EJG (nicotine-type) and 4EJH (NNK-type) (A) and of CYP2A6 4EJJ (nicotinetype) and 3T3R (pilocarpine-type) (B). Points obtained with naphthalene, phenanthrene, and biphenyl are shown in red, other 21 chemicals in open square, and coumarin, indole, NNK, nicotine, and pilocarpine in blue. Abbreviations used in this figure: 4-biphenyl propargyl ether (4BPE), 9-(1-propynyl)phenanthrene (9PPh), 4-butynylbiphenyl (4BuB), 2,2'-biphenyl dipropargyl ether (22BDPE), and 4,4'-biphenyl dipropargyl ether (44BDPE). Data are taken from Shimada et al. (30) with modification.

Inhibition of human P450s by chemopreventive organoselenium compounds. We have previously shown that BSC and $o-, m$-, and $p$-XSC induce reverse type I binding spectra with CYP1A1, 1A2, and 1B1 and inhibit EROD activities catalyzed by these P450 enzymes (81). The affinities of four selenium compounds in interactions with P450 family 1 enzymes were not very different; the $K_{s}$ values obtained in the spectral interactions of four selenium compounds with CYP1A1, 1A2, and 1B1 were 19 30 $\mu \mathrm{M}, 6.3 \sim$ $13 \mu \mathrm{M}$, and 3.6 5.7 $\mu \mathrm{M}$, respectively, and the $\mathrm{IC}_{50}$ values for these chemicals were $0.10 \sim 0.45 \mu \mathrm{M}$ for CYP1A1, $0.20 \sim$ $1.3 \mu \mathrm{M}$ for CYP1A2, and $0.13 \sim 0.27 \mu \mathrm{M}$ for CYP1B1 (Table 4). However, these organoselenium compounds were found to have relatively higher affinities for CYP1B1 than
CYP1A1 and 1A2, because the $K_{s}$ values in CYP1B1 were lower and the $\Delta A_{\max } / K_{s}$ values in CYP1B1 were higher than those in the cases of the latter two enzymes (81).

These four organoselenium compounds also induce type I binding spectra with CYP2A13 and 2A6 and are able to inhibit coumarin 7-hydroxylation activities by these enzymes (Table 4) (25). We concluded that i) four selenium compounds bind to CYP2A6 and 2A13 to induce type I binding spectra (25), ii) both CYP2A13 and 2A6-dependent coumarin 7-hydroxylation activities are significantly inhibited by these selenium compounds (Table 4), and iii) the spectral changes and catalytic inhibition by these chemicals are more profoundly observed with CYP2A13 than CYP2A6 (25). Other human P450 enzymes, such as CYP2C9, 2E1,

Table 4. Inhibition of CYP1A1-, 1A2, and 1B1-dependent EROD activities and CYP2A6- and 2A13-dependent coumarin 7-hydroxylation activities by organoselenium compounds

\begin{tabular}{|c|c|c|c|c|}
\hline \multirow{2}{*}{$\begin{array}{c}\text { (Chemical) } \\
\text { (P450) }\end{array}$} & $\mathrm{BSC}$ & $o-\mathrm{XSC}$ & $m$-XSC & $p$-XSC \\
\hline & \multicolumn{4}{|c|}{$\mathrm{IC}_{50}(\mu \mathrm{M})$ for inhibition of EROD activity } \\
\hline CYP1A1 & $0.45 \pm 0.038$ & $0.11 \pm 0.021$ & $0.10 \pm 0.013$ & $0.26 \pm 0.031$ \\
\hline CYP1A2 & $1.3 \pm 0.22$ & $0.39 \pm 0.042$ & $0.20 \pm 0.021$ & $0.63 \pm 0.059$ \\
\hline CYP1B1 & $0.27 \pm 0.031$ & $0.14 \pm 0.027$ & $0.13 \pm 0.011$ & $0.16 \pm 0.009$ \\
\hline \multirow{2}{*}{$\begin{array}{c}\text { (Chemical) } \\
(\mathrm{P} 450)\end{array}$} & $\mathrm{BSC}$ & $o-\mathrm{XSC}$ & $m$-XSC & $p$-XSC \\
\hline & \multicolumn{4}{|c|}{$\mathrm{IC}_{50}(\mu \mathrm{M})$ for inhibition of coumarin 7-hydroxylation activity } \\
\hline CYP2A6 & $4.3 \pm 0.36$ & $2.7 \pm 0.34$ & $2.4 \pm 0.19$ & $6.2 \pm 0.55$ \\
\hline CYP2A13 & $1.2 \pm 0.19$ & $1.2 \pm 0.13$ & $0.22 \pm 0.031$ & $1.4 \pm 0.21$ \\
\hline
\end{tabular}

$\mathrm{IC}_{50}$ values were obtained by measuring EROD activities for CYP1A1, 1A2, and 1B1 and coumarin 7-hydroxylation activities for CYP2A6 and 2A13. Data for $I_{50}$ values represent means $\pm S E$. Data are taken from from Shimada et al. (25) with modification. 
(A)

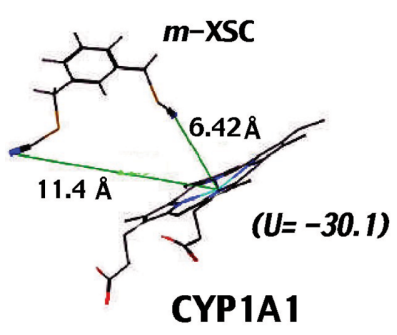

(B)

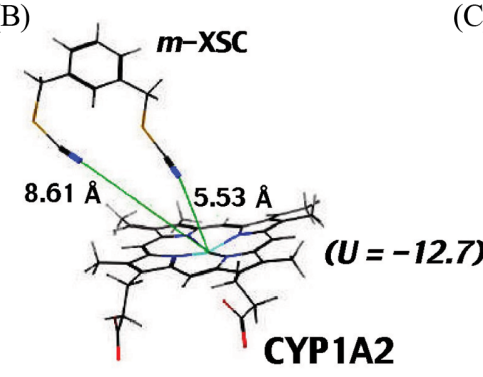

(C)

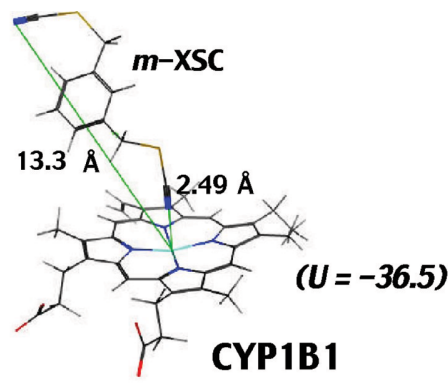

(D)

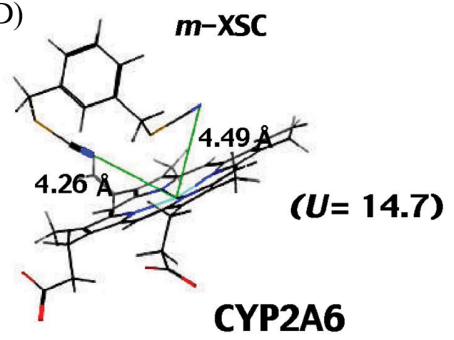

(E)

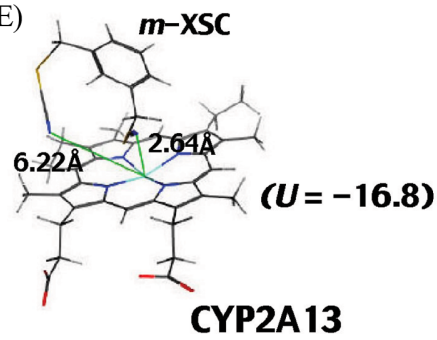

Fig. 9. Molecular docking analysis of interaction of $m-X S C$ with CYP1A1 (A), 1A2 (B), 1B1 (C), 2A6 (D), and 2A13 (E). The ligand-P450 interaction energies ( $U$ values) and distances between the $\mathrm{N}$-atom in one of the $-\mathrm{CH}_{2} \mathrm{SeCN}$ moieties of $m$ - $\mathrm{XSC}$ and the Fe- atom (calculated using in silico analysis) in these P450s are shown in the figure.

and 3A4, do not show any apparent spectral changes with these selenium compounds tested. Thus, one of the mechanisms underlying prevention of cancers caused by PAHs and tobacco-related carcinogens with these selenium compounds is suggested to be due to the results of inhibition of P450 family 1 and 2A enzymes.

Molecular docking analysis was done to see interaction of $m$-XSC with CYP1A1, 1A2, 1B1, 2A6, and 2A13 (Fig. 9). The distances between the $\mathrm{N}$-atom in one of the $-\mathrm{CH}_{2} \mathrm{SeCN}$ moieties of $m$-XSC and the Fe- atom in CYP1A1, 1A2, and 1B1 were calculated in silico analysis. By comparing the distances in CYP1A1, 1A2, and 1B1, it was found that one of the selenium moieties was closely oriented in the active sites of CYP1B1 (2.49 $\AA$ ); these distances were $5.53 \AA$ and $6.42 \AA$ in CYP1A1 and $1 \mathrm{~A} 2$, respectively. In contrast to the cases in P450 family 1 enzymes, both selenium moieties at 1- and 3-positions of $m$-XSC were docked near the heme of CYP2A13 and 2A6 (25). The distance between $\mathrm{N}$-atom of $m$-XSC and the Fe- atom of CYP2A13 (2.64 $\AA$ ) (Fig. 9C) was also close as compared with CYP2A6 (4.26 or $4.49 \AA)$ (Fig. 9D, 9E).

\section{CONCLUSIONS}

Mouse Cyp1b1 and 2a5 have been shown to be important enzymes in initiating cell transformation caused by environmental carcinogens such as 7,12-DMBA, $\mathrm{B}[a] \mathrm{P}$, $\mathrm{DB}[a, l] \mathrm{P}$, and $\mathrm{NNK}$ based on the effects of disruption of respective P450 genes and specific chemical P450 inhibitors on the suppression of tumor formation caused by car- cinogens in vivo. Because human CYP1B1 (and also CYP1A1 and 1A2) and CYP2A13 (and CYP2A6) have been shown to be the major enzymes involved in the activation of these carcinogenic PAHs and tobacco-related nitrosamines in vitro, it is interesting to determine what kinds of xenobiotic chemicals inhibit individual forms of human P450 enzymes. In this review, we have described the nature of various xenobiotic chemicals that inhibit human CYP1 and 2A enzymes; these chemicals include carcinogenic and non- or weak carcinogenic PAHs, arylacetylenes, plant flavonoid derivatives, organoselenium compounds, and other chemicals. Many chemical inhibitors induce type I, type II, and reverse type I spectral changes with specific form(s) of P450 and these spectral intensities often, but not all, relate to the abilities to inhibit and/or to be metabolized by these P450 enzymes. Molecular docking analysis is a useful tool in examining the interactions of chemical inhibitors with P450 enzymes and determining how these chemicals are metabolized by P450 enzymes. Dietary consumption of chemical inhibitors for P450 enzymes and polymorphisms of various P450 genes may affect differences in cancer susceptibilities caused by a variety of environmental carcinogens in humans.

\section{ACKOWLEDGMENTS}

I thank Drs. Masayuki Komori and Shigeo Takenaka (Osaka Prefecture University) for their support, Dr. F. Peter Guengerich (Vanderbilt University) for his support and collaboration for about 33 years, and Drs. Hiroshi Yamazaki 
and Norie Murayama (Showa Pharmaceutical University) for their useful advise and collaboration. Thanks are also due to Drs. Maryam K. Forrozesh (Xavier University of Louisiana), Donghak Kim (Konkuk University), and Kensaku Kakimoto (Osaka Prefectural Institute of Public Health) for their fruitful collaboration.

\section{REFERENCES}

1. Rendic, S. and Guengerich, F.P. (2012) Contributions of human enzymes in carcinogen metabolism. Chem. Res. Toxicol., 25, 1316-1383.

2. Guengerich, F.P. (1988) Roles of cytochrome P-450 enzymes in chemical carcinogenesis and cancer chemotherapy. Cancer Res., 48, 2946-2954.

3. Pelkonen, O. and Nebert, D.W. (1982) Metabolism of polycyclic aromatic hydrocarbons: etiologic role in carcinogenesis. Pharmacol. Rev., 34, 189-222.

4. Jalas, J.R., Hecht, S.S. and Murphy, S.E. (2005) Cytochrome P450 enzymes as catalysts of metabolism of 4-(methylnitrosamino)-1-(3-pyridyl)-1-butanone, a tobacco specific carcinogen. Chem. Res. Toxicol., 18, 95-110.

5. Xue, W. and Warshawsky, D. (2005) Metabolic activation of polycyclic and heterocyclic aromatic hydrocarbons and DNA damage: a review. Toxicol. Appl. Pharmacol., 206, 73-93.

6. Guengerich, F.P. and Shimada, T. (1991) Oxidation of toxic and carcinogenic chemicals by human cytochrome P-450 enzymes. Chem. Res. Toxicol., 4, 391-407.

7. Shimada, T. and Fujii-Kuriyama, Y. (2004) Metabolic activation of polycyclic aromatic hydrocarbons to carcinogens by cytochrome P450 1A1 and 1B1. Cancer Sci., 95, 1-6.

8. Shimada, T. (2006) Xenobiotic-metabolizing enzymes involved in activation and inactivation of carcinogenic polycyclic aromatic hydrocarbons. Drug Metab. Pharmacokinet., 21, 257276.

9. Shimada, T. and Okuda, Y. (1988) Metabolic activation of environmental carcinogens and mutagens by human liver microsomes. Role of cytochrome P-450 homologous to a 3-methylcholanthrene-inducible isozyme in rat liver. Biochem. Pharmacol., 37, 459-465.

10. Shimada, T. and Guengerich, F.P. (1989) Evidence for cytochrome P-450 $0_{\mathrm{NF}}$, the nifedipine oxidase, being the principal enzyme involved in the bioactivation of aflatoxins in human liver. Proc. Natl. Acad. Sci. U.S.A, 86, 462-465.

11. Shimada, T., Iwasaki, M., Martin, M.V. and Guengerich, F.P. (1989) Human liver microsomal cytochrome P-450 enzymes involved in the bioactivation of procarcinogens detected by umu gene response in Salmonella typhimurium TA1535/ pSK1002. Cancer Res., 49, 3218-3228.

12. Shimada, T., Martin, M.V., Pruess-Schwartz, D., Marnett, L.J. and Guengerich, F.P. (1989) Roles of individual human cytochrome P-450 enzymes in the bioactivation of benzo(a)pyrene, 7,8-dihydroxy-7,8-dihydrobenzo(a)pyrene, and other dihydrodiol derivatives of polycyclic aromatic hydrocarbons. Cancer Res., 49, 6304-6312.

13. Aoyama, T., Yamano, S., Guzelian, P.S., Gelboin, H.V. and Gonzalez, F.J. (1990) Five of 12 forms of vaccinia virusexpressed human hepatic cytochrome P450 metabolically acti- vate aflatoxin B1. Proc. Natl. Acad. Sci. U.S.A., 87, 4790-4793.

14. Kitada, M., Taneda, M., Ohta, K., Nagashima, K., Itahashi, K. and Kamataki, T. (1990) Metabolic activation of aflatoxin B1 and 2-amino-3-methylimidazo[4,5-f]-quinoline by human adult and fetal livers. Cancer Res., 50, 2641-2645.

15. Shimada, T., Hayes, C.L., Yamazaki, H., Amin, S., Hecht, S.S., Guengerich, F.P. and Sutter, T.R. (1996) Activation of chemically diverse procarcinogens by human cytochrome P450 1B1. Cancer Res., 56, 2979-2984.

16. Shimada, T., Yun, C.H., Yamazaki, H., Gautier, J.C., Beaune, P.H. and Guengerich, F.P. (1992) Characterization of human lung microsomal cytochrome P-450 1A1 and its role in the oxidation of chemical carcinogens. Mol. Pharmacol., 41, 856864.

17. Yamazaki, H., Inui, Y., Yun, C.H., Guengerich, F.P. and Shimada, T. (1992) Cytochrome P450 2E1 and 2A6 enzymes as major catalysts for metabolic activation of $\mathrm{N}$-nitrosodialkylamines and tobacco-related nitrosamines in human liver microsomes. Carcinogenesis, 13, 1789-1794.

18. Fujita, K. and Kamataki, T. (2001) Role of human cytochrome P450 (CYP) in the metabolic activation of N-alkylnitrosamines: application of genetically engineered Salmonella typhimurium YG7108 expressing each form of CYP together with human NADPH-cytochrome P450 reductase. Mutat. Res., 483, 35-41.

19. Shimada, T., Oda, Y., Gillam, E.M., Guengerich, F.P. and Inoue, K. (2001) Metabolic activation of polycyclic aromatic hydrocarbons and other procarcinogens by cytochromes P450 $1 \mathrm{~A} 1$ and P450 1B1 allelic variants and other human cytochromes P450 in Salmonella typhimurium NM2009. Drug Metab. Dispos., 29, 1176-1182.

20. Shimada, T. and Guengerich, F.P. (2006) Inhibition of human cytochrome P450 1A1-, 1A2-, and 1B1-mediated activation of procarcinogens to genotoxic metabolites by polycyclic aromatic hydrocarbons. Chem. Res. Toxicol., 19, 288-294

21. Shimada, T., Murayama, N., Okada, K., Funae, Y., Yamazaki, H. and Guengerich, F. P. (2007) Different mechanisms of inhibition for human cytochrome P450 1A1, 1A2, and 1B1 by polycyclic aromatic inhibitors. Chem. Res. Toxicol., 20, 489496.

22. Shimada, T., Murayama, N., Tanaka, K., Takenaka, S., Imai, Y., Hopkins, N.E., Foroozesh, M.K., Alworth, W.L., Yamazaki, H., Guengerich, F.P. and Komori, M. (2008) Interaction of polycyclic aromatic hydrocarbons with human cytochrome P450 1B1 in inhibiting catalytic activity. Chem. Res. Toxicol., 21, 2313-2323.

23. Shimada, T., Tanaka, K., Takenaka, S., Foroozesh, M.K., Murayama, N., Yamazaki, H., Guengerich, F.P. and Komori, M. (2009) Reverse type I binding spectra of human cytochrome P450 1B1 induced by flavonoid, stilbene, pyrene, naphthalene, phenanthrene, and biphenyl derivatives that inhibit catalytic activity: a structure-function relationship study. Chem. Res. Toxicol., 22, 1325-1333.

24. Shimada, T., Tanaka, K., Takenaka, S., Murayama, N., Martin, M.V., Foroozesh, M.K., Yamazaki, H., Guengerich, F.P., and Komori, M. (2010) Structure-function relationships of inhibition of human cytochromes P450 1A1, 1A2, 1B1, 2C9, and 3A4 by 33 flavonoid derivatives. Chem. Res. Toxicol., 23, 1921-1935. 
25. Shimada, T., Murayama, N., Tanaka, K., Takenaka, S., Guengerich, F.P., Yamazaki, H. and Komori, M. (2011) Spectral modification and catalytic inhibition of human cytochromes P450 1A1, 1A2, 1B1, 2A6, and 2A13 by four chemopreventive organoselenium compounds. Chem. Res. Toxicol., 24, 1327-1337.

26. Shimada, T., Kim, D., Murayama, N., Tanaka, K., Takenaka, S., Nagy, L.D., Folkman, L.M., Foroozesh, M.K., Komori, M., Yamazaki, H. and Guengerich, F.P. (2013) Binding of diverse environmental chemicals with human cytochromes P450 2A13, 2A6, and 1B1 and enzyme inhibition. Chem. Res. Toxicol., 26, 517-528.

27. Shimada, T., Murayama, N., Yamazaki, H., Tanaka, K., Takenaka, S., Komori, M., Kim, D. and Guengerich F.P. (2013) Metabolic activation of polycyclic aromatic hydrocarbons and aryl and heterocyclic amines by human cytochromes $\mathrm{P} 450$ 2A13 and 2A6. Chem. Res. Toxicol., 26, 529-537.

28. Shimada, T., Takenaka, S., Murayama, N., Yamazaki, H., Kim, J.H., Kim, D., Yoshimoto, F.K., Guengerich, F.P. and Komori, M. (2015) Oxidation of acenaphthene and acenaphthylene by human cytochrome P450 enzymes. Chem. Res. Toxicol., 28, 268-278.

29. Shimada, T., Takenaka, S., Murayama, N., Kramlinger, V.M., Kim, J.H., Kim, D., Liu, J., Foroozesh, M.K., Yamazaki, H., Guengerich, F.P. and Komori, M. (2016) Oxidation of pyrene, 1-hydroxypyrene, 1-nitropyrene and 1-acetylpyrene by human cytochrome P450 2A13. Xenobiotica, 46, 211-224.

30. Shimada, T., Takenaka, S., Kakimoto, K., Murayama, N., Lim, Y.R., Kim, D., Foroozesh, M.K., Yamazaki, H., Guengerich, F.P. and Komori, M. (2016) Structure-function studies of naphthalene, phenanthrene, biphenyl, and their derivatives in interaction with and oxidation by cytochromes P450 2A13 and 2A6. Chem. Res. Toxicol., 29, 1029-1040.

31. Shimada, T., Kakimoto, K., Takenaka, S., Koga, N., Uehara, S., Murayama, N., Yamazaki, H., Kim, D., Guengerich, F.P. and Komori, M. (2016) Roles of human CYP2A6 and monkey CYP2A24 and 2A26 cytochrome P450 enzymes in the oxidation of 2,5,2',5'-tetrachlorobiphenyl. Drug Metab. Dispos., 44, 1899-1909.

32. Buters, J.T., Sakai, S., Richter, T., Pineau, T., Alexander, D.L., Savas, U., Doehmer, J., Ward, J.M., Jefcoate, C.R. and Gonzalez, F.J. (1999) Cytochrome P450 CYP1B1 determines susceptibility to 7,12-dimethylbenz[a]anthracene-induced lymphomas. Proc. Nat. Acad. Sci. U.S.A., 96, 1977-1982.

33. Buters, J., Quintanilla-Martinez, L., Schober, W., Soballa, V.J., Hintermair, J., Wolff, T., Gonzalez, F.J. and Greim, H. (2003) CYP1B1 determines susceptibility to low doses of 7,12-dimethylbenz $[a]$ anthracene-induced ovarian cancers in mice: correlation of CYP1B1-mediated DNA adducts with carcinogenicity. Carcinogenesis, 24, 327-334.

34. Buters, J.T., Mahadevan, B., Quintanilla-Martinez, L., Gonzalez, F.J., Greim, H., Baird, W.M. and Luch, A. (2002) Cytochrome P450 1B1 determines susceptibility to dibenzo[a,l]pyreneinduced tumor formation. Chem. Res. Toxicol., 15, 1127-1135.

35. Buters, J.T., Mahadevan, B., Quintanilla-Martinez, L., Gonzalez, F.J., Greim, H., Baird, W.M. and Luch, A. (2002) Cytochrome $\mathrm{P} 4501 \mathrm{~B} 1$ determines susceptibility to dibenzo[a,l]pyreneinduced tumor formation. Chem. Res. Toxicol., 15, 1127-1135.

36. Siddens, L.K., Bunde, K.L., Harper, T.A., Jr., McQuistan, T.J.,
Löhr, C.V., Bramer, L.M., Waters, K.M., Tilton, S.C., Krueger, S.K., Williams, D.E. and Baird, W.M. (2015) Cytochrome P450 1b1 in polycyclic aromatic hydrocarbon (PAH)-induced skin carcinogenesis: Tumorigenicity of individual PAHs and coal-tar extract, DNA adduction and expression of select genes in the Cyplb1 knockout mouse. Toxicol. Appl. Pharmacol., 287, 149-160.

37. Heidel, S.M., Holston, K., Buters, J.T., Gonzalez, F.J., Jefcoate, C.R. and Czupyrynski, C.J. (1999) Bone marrow stromal cell cytochrome $\mathrm{P} 4501 \mathrm{~B} 1$ is required for pre-B cell apoptosis induced by 7,12-dimethylbenz[a]anthracene. Mol. Pharmacol., 56, 1317-1323.

38. Heidel, S.M., MacWilliams, P.S., Baird, W.M., Dashwood, W.M., Buters, J.T., Gonzalez, F.J., Larsen, M.C., Czuprynski, C.J. and Jefcoate, C.R. (2000) Cytochrome P4501B1 mediates induction of bone marrow cytotoxicity and preleukemia cells in mice treated with 7,12-dimethylbenz[a]anthracene. Cancer Res., 60, 3454-3460.

39. Gao, J., Lauer, F.T., Dunaway, S. and Burchiel, S.W. (2005) Cytochrome P450 1B1 is required for 7,12-dimethylbenz(a)anthracene (DMBA) induced spleen cell immunotoxicity. Toxicol. Sci., 86, 68-74.

40. Miyata, M., Kudo, G., Lee, Y.H., Yang, T.J., Gelboin, H.V., Fernandez-Salguero, P., Kimura, S. and Gonzalez, F.J. (1999) Targeted disruption of the microsomal epoxide hydrolase gene. Microsomal epoxide hydrolase is required for the carcinogenic activity of 7,12-dimethylbenz[a]anthracene. J. Biol. Chem., 274, 23963-23968.

41. Shimizu, Y., Nakatsuru, Y., Ichinose, M., Takahashi, Y., Kume, H., Mimura, J., Fujii-Kuriyama, Y. and Ishikawa, T. (2000) Benzo[a]pyrene carcinogenicity is lost in mice lacking the aryl hydrocarbon receptor. Proc. Natl. Acad. Sci. U.S.A., 97, 779-782.

42. Luch, A., Schober, W., Soballa, V.J., Raab, G., Greim, H., Jacob, J., Doehmer, J. and Seidel, A. (1999) Metabolic activation of dibenzo[a]pyrene by human cytochrome P450 1A1 and P450 1B1 expressed in V79 Chinese hamster cells. Chem. Res. Toxicol., 12, 353-364.

43. Shimada, T., Gillam, E.M., Oda, Y., Tsumura, F., Sutter, T.R., Guengerich, F.P. and Inoue, K. (1999) Metabolism of benzo[a]pyrene to trans-7,8-dihydroxy-7,8-dihydrobenzo[a]pyrene by recombinant human cytochrome P450 1B1 and purified liver epoxide hydrolase. Chem. Res. Toxicol., 12, 623-629.

44. Uno, S., Dalton, T.P., Derkenne, S., Curran, C.P., Miller, M.L., Shertzer, H.G. and Nebert, D.W. (2004) Oral exposure to benzo $[a]$ pyrene in the mouse: detoxication by inducible cytochrome P450 is more important than metabolic activation. Mol. Pharmacol., 65, 1225-1237.

45. Uno, S., Dalton, T.P., Dragin, N., Curran, C.P., Derkenne, S., Miller, M.L., Shertzer, H.G., Gonzalez, F.J. and Nebert, D.W. (2006) Oral benzo[a]pyrene in Cyp1 knockout mice lines: CYP1A1 important in detoxication, CYP1B1 metabolism required for immune damage independent of total-body burden and clearance rate. Mol. Pharmacol., 69, 1103-1114.

46. Nebert, D.W., Shi, Z., Gálvez-Peralta, M., Uno, S. and Dragin, N. (2013) Oral benzo[a]pyrene: understanding pharmacokinetics, detoxication, and consequences--Cyp1 knockout mouse lines as a paradigm. Mol. Pharmacol., 84, 304-313.

47. Megaraj, V., Zhou, X., Xie, F., Liu, Z., Yang, W. and Ding, X. 
(2014) Role of CYP2A13 in the bioactivation and lung tumorigenicity of the tobacco-specific lung procarcinogen 4-(methylnitrosamino)-1-(3-pyridyl)-1-butanone: in vivo studies using a CYP2A13-humanized mouse model. Carcinogenesis, 35, 131-137.

48. Liu, Z., Megaraj, V., Li, L., Sell, S., Hu, J. and Ding X. (2015) Suppression of pulmonary CYP2A13 expression by carcinogen-induced lung tumorigenesis in a CYP2A13-humanized mouse model. Drug Metab. Dispos., 43, 698-702.

49. Hollander, M.C., Zhou, X., Maier, C.R., Patterson, A.D., Ding, X. and Dennis, P.A. (2011) A Cyp2a polymorphism predicts susceptibility to NNK-induced lung tumorigenesis in mice. Carcinogenesis, 32, 1279-1284.

50. Li, L., Megaraj, V., Wei, Y. and Ding, X. (2014) Identification of cytochrome P450 enzymes critical for lung tumorigenesis by the tobacco-specific carcinogen 4-(methylnitrosamino)-1(3-pyridyl)-1-butanone (NNK): insights from a novel Cyp2abfgs-null mouse. Carcinogenesis, 35, 2584-2591.

51. Zhou, X., D'Agostino, J., Xie, F. and Ding, X. (2012) Role of CYP2A5 in the bioactivation of the lung carcinogen 4-(methylnitrosamino)-1-(3-pyridyl)-1-butanone in mice. J. Pharmacol. Exp. Ther., 341, 233-241.

52. Kang, J.S., Wanibuchi, H., Morimura, K., Gonzalez, F.J. and Fukushima, S. (2007) Role of CYP2E1 in diethylnitrosamineinduced hepatocarcinogenesis in vivo. Cancer Res., 67, 1114111146.

53. Gelboin, H.V., Wiebel, F. and Diamond, L. (1970) Dimethylbenzanthracene tumorigenesis and aryl hydrocarbon hydroxylase in mouse skin: inhibition by 7,8-benzoflavone. Science, 170, 169-171.

54. Kinoshita, N. and Gelboin, H.V. (1972) Aryl hydrocarbon hydroxylase and polycyclic hydrocarbon tumorigenesis: effect of the enzyme inhibitor 7,8-benzoflavone on tumorigenesis and macromolecule binding. Proc. Nat. Acad. Sci. U.S.A., 69, 824-828.

55. Kinoshita, N. and Gelboin, H.V. (1972) The role of aryl hydrocarbon hydroxylase in 7,12-dimethylbenz(a)anthracene skin tumorigenesis: on the mechanism of 7,8-benzoflavone inhibition of tumorigenesis. Cancer Res., 32, 1329-1339.

56. Slaga, T.J., Thompson, S., Berry, D.L., Digiovanni, J., Juchau, M.R. and Viaje, A. (1977) The effects of benzoflavones on polycyclic hydrocarbon metabolism and skin tumor initiation. Chem. Biol. Interact., 3, 297-312.

57. Riegel, B., Wartman, W.B., Hill, W.T., Reeb, B.B., Shubik, P. and Stanger, D. W. (1951) Delay of methylcholanthrene skin carcinogenesis in mice by 1,2,5,6-dibenzofluorene. Cancer Res., 11, 301-303.

58. Hill, W.T., Stanger, D.W., Pizzo, A., Riege, B., Shubik, P. and Wartman, W.B. (1951) Inhibition of 9,10-dimethyl-1,2-benzanthracene skin carcinogenesis in mice by polycyclic hydrocarbons. Cancer Res., 11, 892-897.

59. Slaga, T.J., Jecker, L., Bracken, W.M. and Weeks, C.E. (1979) The effects of weak or non-carcinogenic polycyclic hydrocarbons on 7,12-dimethylbenz[a]anthracene and benzo[a]pyrene skin tumor-initiation. Cancer Lett., 7, 51-59.

60. DiGiovanni, J., Rymer, J., Slaga, T.J. and Boutwell, R.K. (1982) Anticarcinogenic and cocarcinogenic effects of benzo[e]pyrene and dibenz[a,c]anthracene on skin tumor initiation by polycyclic hydrocarbons. Carcinogenesis, 3, 371-
375.

61. Smolarek, T.A. and Baird, W.M. (1986) Benzo(e)pyreneinduced alterations in the stereoselectivity of activation of 7,12-dimethylbenz(a)anthracene to DNA-binding metabolites in hamster embryo cell cultures. Cancer Res., 46, 1170-1175.

62. Smolarek, T.A., Baird, W.M., Fisher, E.P. and DiGiovanni, J. (1987) Benzo(e)pyrene-induced alterations in the binding of benzo(a)pyrene and 7,12-dimethylbenz(a)anthracene to DNA in Sencar mouse epidermis. Cancer Res., 47, 3701-3706.

63. Smolarek, T.A. and Baird, W.M. (1984) Benzo[e]pyreneinduced alterations in the binding of benzo[a]pyrene to DNA in hamster embryo cell cultures. Carcinogenesis, 8, 10651069.

64. Baird, W.M., Salmon, C.P. and Diamond, L. (1984) Benzo(e)pyrene-induced alterations in the metabolic activation of benzo(a)pyrene and 7,12-dimethylbenz(a)anthracene by hamster embryo cells. Cancer Res., 44, 1445-1452.

65. Lesca, P. and Mansuy, D. (1980) 9-Hydroxyellipticine: inhibitory effect on skin carcinogenesis induced in Swiss mice by 7,12-dimethylbenz[a]anthracene. Chem. Biol. Interact., 30, 181-187.

66. Alworth, W.L., Viaje, A., Sandoval, A., Warren, B.S. and Slaga, T.J. (1991) Potent inhibitory effects of suicide inhibitors of P450 isozymes on 7,12-dimethylbenz[a]anthracene and benzo[a]pyrene initiated skin tumors. Carcinogenesis, 7, 1209-1215.

67. Cai, Y., Baer-Dubowska, W., Ashwood-Smith, M. and DiGiovanni, J. (1997) Inhibitory effects of naturally occurring coumarins on the metabolic activation of benzo[a]pyrene and 7,12-dimethylbenz[a]anthracene in cultured mouse keratinocytes. Carcinogenesis, 18, 215-222.

68. Kleiner, H.E., Vulimiri, S.V., Reed, M.J., Uberecken, A. and DiGiovanni, J. (2002) Role of cytochrome P450 1a1 and 1b1 in the metabolic activation of 7,12-dimethylbenz[a]anthracene and the effects of naturally ocurring furanocoumarins on skin tumor intitiation. Chem. Res. Toxicol., 15, 226-235.

69. Kleiner, H.E., Reed, M.J. and DiGiovanni, J. (2003) Naturally occurring coumarins inhibit human cytochromes P450 and block benzo[a]pyrene and 7,12-dimethylbenz[a]anthracene DNA adduct formation in MCF-7 cells. Chem. Res. Toxicol., 16, 415-422.

70. Sulfikkarali, N., Krishnakumar, N., Manoharan, S. and Nirmal, R.M. (2013) Chemopreventive efficacy of naringeninloaded nanoparticles in 7,12-dimethylbenz(a)anthracene induced experimental oral carcinogenesis. Pathol. Oncol. Res., 19, 287-296.

71. Silvan, S., Manoharan, S., Baskaran, N., Anusuya, C., Karthikeyan, S. and Prabhakar, M.M. (2011) Chemopreventive potential of apigenin in 7,12-dimethylbenz(a)anthracene induced experimental oral carcinogenesis. Eur. J. Pharmacol., 670, 571-577.

72. Kassie, F., Anderson, L.B., Scherber, R., Yu, N., Lahti, D., Upadhyaya, P. and Hecht, S.S. (2007) Indole-3-carbinol inhibits 4-(methylnitrosamino)-1-(3-pyridyl)-1-butanone plus benzo(a)pyrene-induced lung tumorigenesis in $\mathrm{A} / \mathrm{J}$ mice and modulates carcinogen-induced alterations in protein levels. Cancer Res., 67, 6502-6511.

73. Tanaka, T., Makita, H., Kawabata, K., Mori, H., Kakumoto, M., Satoh, K., Hara, A., Sumida, T., Tanaka, T. and Ogawa, H. 
(1997) Chemoprevention of azoxymethane-induced rat colon carcinogenesis by the naturally occurring flavonoids, diosmin and hesperidin. Carcinogenesis, 18, 957-965.

74. Takeuchi, H., Saoo, K., Matsuda, Y., Yokohira, M., Yamakawa, K., Zeng, Y., Kuno, T., Kamataki, T. and Imaida, K. (2009) 8Methoxypsoralen, a potent human CYP2A6 inhibitor, inhibits lung adenocarcinoma development induced by 4-(methylnitrosamino)-1-(3-pyridyl)-1-butanone in female A/J mice. Mol. Med. Rep., 2, 585-588.

75. Takeuchi, H., Saoo, K., Yokohira, M., Ikeda, M., Maeta, H., Miyazaki, M., Yamazaki, H., Kamataki, T. and Imaida, K. (2003) Pretreatment with 8-methoxypsoralen, a potent human CYP2A6 inhibitor, strongly inhibits lung tumorigenesis induced by 4-(methylnitrosamino)-1-(3-pyridyl)-1-butanone in female A/J mice. Cancer Res., 63, 7581-7583.

76. Miyazaki, M., Yamazaki, H., Takeuchi, H., Saoo, K., Yokohira, M., Masumura, K., Nohmi, T., Funae, Y., Imaida, K. and Kamataki. T. (2005) Mechanisms of chemopreventive effects of 8-methoxypsoralen against 4-(methylnitrosamino)-1-(3pyridyl)-1-butanone-induced mouse lung adenomas. Carcinogenesis, 26, 1947-1955.

77. Takeuchi, H., Saoo, K., Matsuda, Y., Yokohira, M., Yamakawa, K., Zeng, Y., Miyazaki, M., Fujieda, M., Kamataki, T. and Imaida, K. (2006) Dose dependent inhibitory effects of dietary 8-methoxypsoralen on NNK-induced lung tumorigenesis in female A/J mice. Cancer Lett., 234, 232-238.

78. Wattenberg, L.W. (1987) Inhibitory effects of benzyl isothiocyanate administered shortly before diethylnitrosamine or benzo $[a]$ pyrene on pulmonary and forestomach neoplasia in A/J mice. Carcinogenesis, 8, 1971-1973.

79. Morse, M.A., Eklind, K.I., Amin, S.G., Hecht, S.S. and Chung, F.L. (1989) Effects of alkyl chain length on the inhibition of NNK-induced lung neoplasia in A/J mice by arylalkyl isothiocyanates. Carcinogenesis, 10, 1757-1759.

80. Morse, M.A., Amin, S.G., Hecht, S.S. and Chung, F.L. (1989) Effects of aromatic isothiocyanates on tumorigenicity, $\mathrm{O}^{6}$ methylguanine formation, and metabolism of the tobacco-specific nitrosamine 4-(methylnitrosamino)-1-(3-pyridyl)-1-butanone in A/J mouse lung. Cancer Res., 49, 2894-2897.

81. Shimada, T., El-Bayoumy, K., Upadhyaya, P., Sutter, T.R., Guengerich, F.P. and Yamazaki, H. (1997) Inhibition of human cytochrome P450-catalyzed oxidations of xenobiotics and procarcinogens by synthetic organoselenium compounds. Cancer Res., 57, 4757-4764.

82. Fiala, E.S., Joseph, C., Sohn, O.S., El-Bayoumy, K. and Reddy, B.S. (1991) Mechanism of benzylselenocyanate inhibition of azoxymethane-induced colon carcinogenesis in F344 rats. Cancer Res., 51, 2826-2830.

83. von Weymarn, L.B., Chun, J.A. and Hollenberg, P.F. (2006) Effects of benzyl and phenethyl isothiocyanate on P450s 2A6 and 2A13: potential for chemoprevention in smokers. Carcinogenesis, 27, 782-790.

84. El-Bayoumy, K., Chae, Y.H., Upadhyaya, P., Meschter, C., Cohen, L.A. and Reddy, B.S. (1992) Inhibition of 7,12dimethylbenz(a)anthracene-induced tumors and DNA adduct formation in the mammary glands of female Sprague-Dawley rats by the synthetic organoselenium compound, 1,4-phenylenebis(methylene)selenocyanate. Cancer Res., 52, 2402-2407.

85. Prokopczyk, B., Cox, J.E., Upadhyaya, P., Amin, S., Desai, D.,
Hoffmann, D. and El-Bayoumy, K. (1996) Effects of dietary 1,4-phenylenebis(methylene)selenocyanate on 4-(methylnitrosamino)-1-(3-pyridyl)-1-butanone-induced DNA adduct formation in lung and liver of $\mathrm{A} / \mathrm{J}$ mice and $\mathrm{F} 344$ rats. Carcinogenesis, 17, 749-753.

86. Prokopczyk, B., Rosa, J.G., Desai, D., Amin, S., Sohn, O.S., Fiala, E.S. and El-Bayoumy, K. (2000) Chemoprevention of lung tumorigenesis induced by a mixture of benzo(a)pyrene and 4-(methylnitrosamino)-1-(3-pyridyl)-1-butanone by the organoselenium compound 1,4-phenylenebis(methylene)selenocyanate. Cancer Lett., 161, 35-46.

87. El-Bayoumy, K., Das, A., Boyiri, T., Desai, D., Sinha, R., Pittman, B. and Amin, S. (2003) Comparative action of 1,4phenylenebis(methylene)selenocyanate and its metabolites against 7,12-dimethylbenz $[a]$ anthracene-DNA adduct formation in the rat and cell proliferation in rat mammary tumor cells. Chem. Biol. Interact., 146, 179-190.

88. El-Bayoumy, K., Sinha, R., Pinto, J.T. and Rivlin, R.S. (2006) Cancer chemoprevention by garlic and garlic-containing sulfur and selenium compounds. J. Nutr., 136, 864S-869S.

89. El-Bayoumy, K. (1985) Effects of organoselenium compounds on induction of mouse forestomach tumors by benzo(a)pyrene. Cancer Res., 45, 3631-3635.

90. Pelkonen, O., Turpeinen, M., Hakkola, J., Honkakoski, P., Hukkanen, J. and Raunio, H. (2008) Inhibition and induction of human cytochrome P450 enzymes: current status. Arch. Toxicol., 82, 667-715.

91. Pelkonen, O., Mäenpää, J., Taavitsainen, P., Rautio, A. and Raunio, H. (1998) Inhibition and induction of human cytochrome P450 (CYP) enzymes. Xenobiotica, 28, 1203-1253.

92. Fowler, S. and Zhang, H. (2008) In vitro evaluation of reversible and irreversible cytochrome P450 inhibition: current status on methodologies and their utility for predicting drugdrug interactions. AAPS J., 10, 410-424.

93. Hisaka, A., Ohno, Y., Yamamoto, T. and Suzuki, H. (2010) Prediction of pharmacokinetic drug-drug interaction caused by changes in cytochrome $\mathrm{P} 450$ activity using in vivo information. Pharmacol. Ther., 125, 230-248.

94. Niwa, T., Murayama, N. and Yamazaki, H. (2011) Stereoselectivity of human cytochrome P450 in metabolic and inhibitory activities. Curr. Drug Metab., 12, 549-569.

95. Zhang, Z.Y. and Wong, Y.N. (2005) Enzyme kinetics for clinically relevant CYP inhibition. Curr. Drug Metab., 6, 241-257.

96. Ansede, J.H. and Thakker, D.R. (2004) High-throughput screening for stability and inhibitory activity of compounds toward cytochrome P450-mediated metabolism. J. Pharm. Sci., 93, 239-255.

97. Kamel, A. and Harriman, S. (2013) Inhibition of cytochrome P450 enzymes and biochemical aspects of mechanism-based inactivation (MBI). Drug Discov. Today Technol., 10, e177-e189.

98. Okino, S.T., Quattrochi, L.C., Barnes, H.J., Osanto, S., Griffin, K.J., Johnson, E.F. and Tukey, R.H. (1985) Cloning and characterization of cDNAs encoding 2,3,7,8-tetrachlorodibenzo$p$-dioxin-inducible rabbit mRNAs for cytochrome P-450 isozymes 4 and 6. Proc. Natl. Acad. Sci. U.S.A., 82, 5310-5314.

99. Quattrochi, L.C., Okino, S.T., Pendurthi, U.R. and Tukey, R.H. (1985) Cloning and isolation of human cytochrome P450 cDNAs homologous to dioxin-inducible rabbit mRNAs encoding P-450 4 and P-450 6. DNA, 4, 395-400. 
100. Jaiswal, A.K., Nebert, D.W. and Gonzalez, F.J. (1986) Human P3(450): cDNA and complete amino acid sequence. Nucleic Acids Res., 14, 6773-6774.

101. Sutter, T.R., Tang, Y.M., Hayes, C.L., Wo, Y.Y., Jabs, E.W., Li, X., Yin, H., Cody, C.W. and Greenlee, W.F. (1994) Complete cDNA sequence of a human dioxin-inducible mRNA identifies a new gene subfamily of cytochrome P450 that maps to chromosome 2. J. Biol. Chem., 269, 13092-13099.

102. Sansen, S., Yano, J.K., Reynald, R.L., Schoch, G.A., Griffin, K.J., Stout, C.D. and Johnson, E.F. (2007) Adaptations for the oxidation of polycyclic aromatic hydrocarbons exhibited by the structure of human P450 1A2. J. Biol. Chem., 282, 14348-14355.

103. Wang, A., Savas, U., Stout, C.D. and Johnson, E.F. (2011) Structural characterization of the complex between alphanaphthoflavone and human cytochrome P450 1B1. J. Biol. Chem., 286, 5736-5743.

104. Walsh, A.A., Szklarz, G.D. and Scott, E.E. (2013) Human cytochrome P4501A1structure and utility in understanding drug and xenobiotic metabolism. J. Biol. Chem., 288, 1293212943.

105. Chang, T.K., Gonzalez, F.J. and Waxman, D.J. (1994) Evaluation of triacetyloleandomycin, alpha-naphthoflavone and diethyldithiocarbamate as selective chemical probes for inhibition of human cytochromes P450. Arch. Biochem. Biophys., 311, 437-442.

106. Koley, A.P., Buters, J.T., Robinson, R.C., Markowitz, A. and Friedman, F.K. (1997) Differential mechanisms of cytochrome P450inhibition and activation by alpha-naphthoflavone. $J$. Biol. Chem., 272, 3149-3152.

107. Zhai, S., Dai, R., Friedman, F.K. and Vestal, R.E. (1998) Comparative inhibition of human cytochromes P450 1A1 and 1A2 by flavonoids. Drug Metab. Dispos., 26, 989-992.

108. Liu, J., Sridhar, J. and Foroozesh, M. (2013) Cytochrome P450 family 1 inhibitors and structure-activity relationships. Molecules, 18, 14470-14495.

109. Sridhar, J., Liu, J., Foroozesh, M. and Stevens, C.L. (2012) Insights on cytochrome p450 enzymes and inhibitors obtained through QSAR studies. Molecules, 17, 9283-9305.

110. Shimada, T., Wunsch, R.M., Hanna, I.H., Sutter, T.R., Guengerich, F.P. and Gillam, E.M. (1998) Recombinant human cytochrome P4501B1 expression in Escherichia coli. Arch. Biochem. Biophys., 357, 111-120.

111. Shimada, T., Gillam, E.M., Sutter, T.R., Strickland, P.T., Guengerich, F.P. and Yamazaki, H. (1997) Oxidation of xenobiotics by recombinant human cytochrome P4501B1. Drug Metab. Dispos., 25, 617-622.

112. Shimada, T., Yamazaki, H., Foroozesh, M., Hopkins, N.E., Alworth, W.L. and Guengerich, F.P. (1998) Selectivity of polycyclic inhibitors for human cytochrome P450s 1A1, 1A2, and 1B1. Chem. Res. Toxicol., 11, 1048-1056.

113. Rubin, H. (2001) Synergistic mechanisms in carcinogenesis by polycyclic aromatic hydrocarbons and by tobacco smoke: a bio-historical perspective with updates. Carcinogenesis, 22, 1903-1930.

114. Marston, C.P., Pereira, C., Ferguson, J., Fischer, K., Hedstrom, O., Dashwood, W.M. and Baird, W.M. (2001) Effect of a complex environmental mixture from coal tar containing polycyclic aromatic hydrocarbons $(\mathrm{PAH})$ on the tumor initiation, PAH-DNA binding and metabolic activation of carcinogenic PAH in mouse epidermis. Carcinogenesis, 22, 1077-1086.

115. Mahadevan, B., Parsons, H., Musafia, T., Sharma, A.K., Amin, S., Pereira, C. and Baird, W.M. (2004) Effect of artificial mixtures of environmental polycyclic aromatic hydrocarbons present in coal tar, urban dust, and diesel exhaust particulates on MCF-7 cells in culture. Environ. Mol. Mutagen., 44, 99-107.

116. Mahadevan, B., Marston, C.P., Dashwood, W.M., Li, Y., Pereira, C. and Baird, W.M. (2005) Effect of a standardized complex mixture derived from coal tar on the metabolic activation of carcinogenic polycyclic aromatic hydrocarbons in human cells in culture. Chem. Res. Toxicol., 18, 224-231.

117. Jarvis, I.W., Dreij, K., Mattsson, Å., Jernström, B. and Stenius, U. (2014) Interactions between polycyclic aromatic hydrocarbons in complex mixtures and implications for cancer risk assessment. Toxicology, 321, 27-39.

118. Foroozesh, M.K., Primrose, G., Guo, Z., Bell, L.C., Alworth, W.L. and Guengerich, F.P. (1997) Aryl acetylenes as mechanism-based inhibitors of cytochrome P450-dependent monooxygenase enzymes. Chem. Res. Toxicol., 10, 91-102.

119. Hopkins, N.E., Foroozesh, M.K. and Alworth, W.L. (1992) Suicide inhibitors of cytochrome P450 1A1 and P450 2B1. Biochem. Pharmacol., 44, 787-796.

120. Foroozesh, M., Primrose, G., Guo, Z., Bell, L.C., Guengerich, F.P. and Alworth, W.L. (1997) Propynylaryl acetylenes as mechanism-based inhibitors of cytochrome P450 1A1, 1A2, and 2B1 enzymes. Chem. Res. Toxicol., 10, 91-102.

121. Arct, J. and Pytkowska, K. (2008) Flavonoids as components of biologically active cosmeceuticals. Clin. Dermatol., 26, 347-357.

122. Kale, A., Gawande, S. and Kotwal, S. (2008) Cancer phytotherapeutics: role for flavonoids at the cellular level. Phytother. Res., 22, 567-577.

123. Zhang, S., Yang, X., Coburn, R.A. and Morris, M.E. (2005) Structure activity relationships and quantitative structure activity relationships for the flavonoid-mediated inhibition of breast cancer resistance protein. Biochem. Pharmacol., 70, 627-639.

124. Walle, T. (2007) Methoxylated flavones, a superior cancer chemopreventive flavonoid subclass? Semin. Cancer Biol., 17, 354-362.

125. Walle, U.K. and Walle, T. (2007) Bioavailable flavonoids: cytochrome P450-mediated metabolism of methoxyflavones. Drug Metab. Dispos., 35, 1985-1989.

126. Hodek, P., Trefil, P. and Stiborová, M. (2002) Flavonoidspotent and versatile biologically active compounds interacting with cytochromes P450. Chem. Biol. Interact., 139, 1-21.

127. Chun, Y.J., Kim, S., Kim, D., Lee, S.K. and Guengerich, F.P. (2001) A new selective and potent inhibitor of human cytochrome P4501B1 and its application to antimutagenesis. Cancer Res., 61, 8164-8170.

128. Mammen, J.S., Kleiner, H.E., DiGiovanni, J., Sutter, T.R. and Strickland, P.T. (2005) Coumarins are competitive inhibitors of cytochrome P450 1B1, with equal potency for allelic variants. Pharmacogenet. Genomics, 15, 183-188.

129. Kim, H.J., Lee, S.B., Park, S.K., Kim, H.M., Park, Y.I. and Dong, M.S. (2005) Effects of hydroxy group numbers on the 
B-ring of 5,7-dihydroxyflavones on the differential inhibition of human CYP 1A and CYP1B1 enzymes. Arch. Pharm. Res., 28, 1114-1121.

130. Tsujimoto, M., Horie, M., Honda, H., Takara, K. and Nishiguchi, K. (2009) The structure-activity correlation on the inhibitory effects of flavonoids on cytochrome P450 3A activity. Biol. Pharm. Bull., 32, 671-676.

131. Doostdar, H., Burke, M.D. and Mayer, R.T. (2000) Bioflavonoids: selective substrates and inhibitors for cytochrome P450 CYP1A and CYP1B1. Toxicology, 144, 31-38.

132. Otake, Y. and Walle, T. (2002) Oxidation of the flavonoids galangin and kaempferide by human liver microsomes and CYP1A1, CYP1A2, and CYP2C9. Drug Metab. Dispos., 30, 103-105.

133. Si, D., Wang, Y., Zhou, Y.H., Guo, Y., Wang, J., Zhou, H., Li, Z.S. and Fawcett, J.P. (2008) Mechanism of CYP2C9 inhibition by flavones and flavonols. Drug Metab. Dispos., 37, 629-634.

134. Zhai, S., Dai, R., Friedman, F.K. and Vestal, R.E. (1998) Comparative inhibition of human cytochromes P450 1A1 and $1 \mathrm{~A} 2$ by flavonoids. Drug Metab. Dispos., 26, 989-992.

135. Kimura, Y., Ito, H., Ohnishi, R. and Hatano, T. (2010) Inhibitory effects of polyphenols on human cytochrome P450 3A4 and 2C9 activity. Food Chem. Toxicol., 48, 429-435.

136. Quintieri, L., Palatini, P., Nassi, A., Ruzza, P. and Floreani, M. (2008) Flavonoids diosmetin and luteolin inhibit midazolam metabolism by human liver microsomes and recombinant CYP 3A4 and CYP3A5 enzymes. Biochem. Pharmacol., 75, 1426-1437.

137. Roberts, D.W., Doerge, D.R., Churchwell, M.I., Gamboa da Costa, G., Marques, M.M. and Tolleson, W.H. (2004) Inhibition of extrahepatic human cytochromes P450 1A1 and 1B1 by metabolism of isoflavones found in Trifolium pratense (red clover). J. Agric. Food Chem., 52, 6623-6632.

138. Chiang, H.C., Wang, C.K. and Tsou, T.C. (2012) Differential distribution of CYP2A6 and CYP2A13 in the human respiratory tract. Respiration, 84, 319-326.

139. Zhu, L.R., Thomas, P.E., Lu, G., Reuhl, K.R., Yang, G.Y., Wang, L.D., Wang, S.L., Yang, C.S., He, X.Y. and Hong, J.Y. (2006) CYP2A13 in human respiratory tissues and lung cancers: an immunohistochemical study with a new peptide-specific antibody. Drug Metab. Dispos., 34, 1672-1676.

140. Pelkonen, O., Rautio, A., Raunio, H. and Pasanen, M. (2000) CYP2A6: a human coumarin 7-hydroxylase. Toxicology, 144, 139-147.

141. Su, T., Bao, Z., Zhang, Q.Y., Smith, T.J., Hong, J.Y. and Ding, X. (2000) Human cytochrome P450 CYP2A13: Predominant exression in the respiratory tract and its high efficiency metabolic activation of a tobacco-specific carcinogen, 4-(methylnitrosamino)-1-(3-pyridyl)-1-butanone. Cancer Res., 60, 5074-5079.

142. Smith, B.D., Sanders, J.L., Porubsky, P.R., Lushington, G.H., Stout, C.D. and Scott, E.E. (2007) Structure of the human lung cytochrome P450 2A13. J. Biol. Chem., 282, 1730617313.

143. DeVore, N.M. and Scott, E.E. (2012) Nicotine and 4-(methylnitrosamino)-1-(3-pyridyl)-1-butanone binding and access channel in human cytochrome P450 2A6 and 2A13 enzymes. J. Biol. Chem., 287, 26576-26585.

144. DeVore, N.M., Meneely, K.M., Bart, A.G., Stephens, E.S., Battaile, K.P. and Scott, E.E. (2012) Structural comparison of cytochromes P450 2A6, 2A13, and 2E1 with pilocarpine. FEBS J., 279, 1621-1631.

145. Yano, J.K., Hsu, M.H., Griffin, K.J., Stout, C.D. and Johnson, E.F. (2005) Structures of human microsomal cytochrome P450 2A6 complexed with coumarin and methoxsalen. Nat. Struct. Mol. Biol., 12, 822-823.

146. Sansen, S., Hsu, M.H., Stout, C.D. and Johnson, E.F. (2007) Structural insight into the altered substrate specificity of human cytochrome P450 2A6 mutants. Arch. Biochem. Biophys., 464, 197-206. 